\title{
Nontuberculous Mycobacteria Prevalence in Bats' Guano from Caves and Attics of Buildings Studied by Culture and qPCR Examinations
}

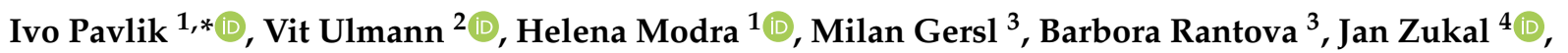 \\ Katerina Zukalova ${ }^{5}$, Ondrej Konecny ${ }^{1}{ }^{1}$, Vlastislav Kana ${ }^{6}$, Pavel Kubalek ${ }^{7}$, Vladimir Babak ${ }^{8} \mathbb{D}$ and \\ Ross Tim Weston ${ }^{9}$
}

Citation: Pavlik, I.; Ulmann, V.; Modra, H.; Gersl, M.; Rantova, B.; Zukal, J.; Zukalova, K.; Konecny, O.; Kana, V.; Kubalek, P.; et al.

Nontuberculous Mycobacteria Prevalence in Bats' Guano from Caves and Attics of Buildings Studied by Culture and qPCR Examinations. Microorganisms 2021, 9, 2236. https:// doi.org/10.3390/microorganisms 9112236

Academic Editor: Hiroyuki Yamada

Received: 14 September 2021

Accepted: 25 October 2021

Published: 27 October 2021

Publisher's Note: MDPI stays neutral with regard to jurisdictional claims in published maps and institutional affiliations.

Copyright: (c) 2021 by the authors. Licensee MDPI, Basel, Switzerland. This article is an open access article distributed under the terms and conditions of the Creative Commons Attribution (CC BY) license (https:/ / creativecommons.org/licenses/by/ $4.0 /)$
1 Faculty of Regional Development and International Studies, Mendel University in Brno, Tr. Generala Piky 7, 61300 Brno, Czech Republic; helena.modra@mendelu.cz (H.M.); ondrej.konecny@mendelu.cz (O.K.)

2 Public Health Institute Ostrava, Partyzanske Nam. 7, 70200 Ostrava, Czech Republic; vit.ulmann@zuova.cz

3 Faculty of AgriSciences, Mendel University in Brno, Zemedelska 1/1665, 61300 Brno, Czech Republic; milan.gersl@mendelu.cz (M.G.); barbora.rantova@mendelu.cz (B.R.)

4 Institute of Vertebrate Biology of the Czech Academy of Sciences, v.v.i., Kvetna 8, 60365 Brno, Czech Republic; zukal@ivb.cz

5 Faculty of Veterinary Hygiene and Ecology, University of Veterinary Sciences Brno, Palackeho Tr. 1946/1, 61242 Brno, Czech Republic; H20363@vfu.cz

6 Museum Blanenska, Zamek 1/1, 67801 Blansko, Czech Republic; prirodovedec@muzeum-blanenska.cz

7 Central Bohemian Archaeological Heritage Institute, Nad Olsinami 448/3, 10000 Prague, Czech Republic; pavel.kubalek@seznam.cz

8 Veterinary Research Institute, v.v.i., Hudcova 70, 62100 Brno, Czech Republic; babak@vri.cz

9 Department of Biochemistry and Genetics, La Trobe Institute for Molecular Science, La Trobe University, Bundoora, Melbourne, VIC 3086, Australia; R.Weston@latrobe.edu.au

* Correspondence: ivo.pavlik@mendelu.cz; Tel.: +420-773-491-836

\begin{abstract}
A total of 281 guano samples were collected from caves $(\mathrm{N}=181)$ in eight European countries (Bulgaria, Czech Republic, France, Hungary, Italy, Romania, Slovakia and Slovenia) and attics in the Czech $\mathrm{R}$. $(\mathrm{N}=100)$. The correlation of detection of mycobacteria between Ziehl-Neelsen (ZN) microscopy and culture examination and qPCR was strong. ZN microscopy was positive in guano from caves $(58.6 \%)$ more than double than positivity in guano from attics $(21.0 \% ; p<0.01)$ From 89 mycobacterial isolates (73 isolates from cave guano and 16 isolates from attics' guano), $68(76.4 \%)$ isolates of 19 sp., ssp. and complex were identified as members of three Groups $(M$. fortuitum, M. chelonae, and M. mucogenicum) and four complexes (M. avium, M. terrae, M. vaccae, and M. smegmatis). A total of 20 isolates (22.5\%) belonged to risk group 1 (environmental saprophytes), 48 isolates $(53.9 \%)$ belonged to risk group 2 (potential pathogens), and none of the isolates belonged to risk group 3 (obligatory pathogens). When comparing bat guano collected from caves and attics, differences ( $p<0.01$; Mann-Whitney test) were observed for the electrical conductivity, total carbon, total organic, and total inorganic carbon. No difference ( $p>0.05$; Mann-Whitney test) was found for $\mathrm{pH}$ and oxidation-reduction potential parameters.
\end{abstract}

Keywords: non-tuberculous mycobacteria (NTM); mycobacteria other than tuberculosis (MOTT); saprophytic environmental mycobacteria; risk groups of microorganisms; microchiroptera

\section{Introduction}

Bats are well known for being reservoirs for many different pathogenic agents [1-3]. Most of the recent interest in this field has been focused on viruses [4-7], however, bats can also host a wide range of fungi $[8,9]$ and protozoa $[10,11]$. While knowledge of presence of different pathogens in bats continues to grow, very little is known about the pathogenicity of bacteria in bats [2,12]. Previous studies have shown bats carrying Anaplasma phagocytophilum [13], Bartonella spp. [14-18], Coxiealla spp. [19], Enterococcus faecalis [20], Leptospira 
spp. [15,21], mycoplasmas [22,23], Pasteurella multocida [24], Rickettsia [18], Staphylococcus nepalensis [25], or Streptomyces sp. [26]. Antibiotic-resistant bacteria from bat faecal microbiome was studied in Myotis myotis and Rhinolophus hipposideros in Slovakia [27].

However, there is a clear lack of knowledge on the presence of species of the family Mycobacteriaceae in bats [2,28]. The first reports describing Mycobacterium bovis isolation from an Indian Flying fox (Pteropus giganteus) living in captivity in zoological gardens in the UK were published between 1925 and 1931 [29-31]. The anamnestic data of all these three cases revealed that the animals were occasionally fed condensed milk, which could naturally be contaminated with $M$. bovis from infected cows. Subsequently, non-photochromogenic nontuberculous mycobacteria (NTM) belonging to III Runyon Group [32] were isolated from the livers of 10 Brazilian free-tailed bats (Tadarida brasiliensis) in Eagle Creek in the USA in 1969 [8].

Bats have also been used as an experimental animal model for mycobacterial infections. In 1963, successful infection in the footpad of Eastern Pipistrelle (Pipistrellus subflavus) and Florida Free-tailed Bat (Tadarida brasiliensis ssp. cynocephala) with M. marinum was demonstrated. Several bats developed footpad lesions (site of infection) similar to those in mice, but none developed significant visceral infections within the period they were kept alive, usually 5-14 days after the infection [33]. A later investigation involved Strawcolored Fruit Bats (Eidolon helvum) artificially infected with M. ulcerans, and re-isolation of this mycobacterial species from web muscles 4 weeks after infection [34]. In 1972, bats were considered as a possible reservoir of M. ulcerans infection in Australia [35], although this was not confirmed [36].

Microbiome analyses revealed the abundance of phylum Actinobacteria (including family Mycobacteriaceae) in subtropical and tropical bats' droppings (pellets) examined $2 \mathrm{~h}$ after defecation or in bat guano (bat feces older than $2 \mathrm{~h}$ ). Isolates from this phylum made up 64.1\% [37], 30.0\% [38], and 22.6\% [39] of the microbiome from three studies in India, and $34.9 \%$ in a study from the Philippines [40]. In contrast, in Finland, phylum Actinobacteria represented less than $0.01 \%$ of the microbiome in bat guano [16].

Actinobacteria were observed in the gastrointestinal tract of bats in China. In this study, Actinobacteria were present in only $2.4 \%$ of stomach samples but were present in $15.7 \%$ of intestinal samples [41]. In contrast, Selvin et al. [42] detected Actinobacteria in $32.5 \%$ of guano samples along with Proteobacteria and Firmicutes in $70.9 \%$ and $24.9 \%$ of guano samples, respectively, however very low numbers of Actinobacteria were present in the gut samples of bat (Rhinolophus monoceros) in another study in India.

In a previous study, we cultured $M$. fortuitum and M. peregrinum from guano samples from one cave in a Moravian Karst [43]. However, genus Mycobacterium is immensely large and comprises more than 195 currently known validated sp. and ssp. From a clinical point of view, only eight species including $M$. tuberculosis and $M$. bovis are serious human and animal pathogens (List of Prokaryotic Names with Standing in Nomenclature; LPSN) [44] also known as tuberculous mycobacteria [36]. These eight species (M. africanum, M. bovis, M. caprae, M. leprae, M. pinnipedii, $M$. tuberculosis, M. microti, and M. ulcerans) belong to the risk group 3 of biological agents that can cause severe human disease and are at risk of spreading into the community; although effective prophylaxis or treatment is usually available (Directive 2000/54/EC and LPSN) [44,45]. The remaining 187 sp. and ssp. (95.9\%) belong to a large group of so-called nontuberculous or environmental mycobacteria [36]. According to the clinical relevance to humans and animals, 99 (50.8\%) of NTM sp. and ssp. are in the risk group 1 of biological agents that are unlikely to cause human diseases. A total of $86(44.1 \%)$ of NTM sp. and ssp. are in risk group 2 of biological agents that can cause human disease but that are unlikely to be spread to the community and there are usually effective prophylaxis or treatment available. Only M. yongonense has yet to be evaluated and designated a risk group classification as of July 2021 (Directive 2000/54/EC and LPSN) [44,45].

Physico-chemical parameters ( $\mathrm{pH}$, organic carbon, etc.) were studied in bat guano collected from caves in a Slovak Karst (Domica Cave) in relation to diversity of Archaeal 
community [46]. In Italy, the geochemistry ( $\mathrm{pH}$, electrical conductivity etc.) of guano was studied in relation to microbial diversity of cave waters in the gypsum karst aquifer [47]. There is the question: which chemical and physical conditions in bats' guano can protect mycobacteria survival or even stimulate the mycobacteria growth?

Underground and sheltered spaces including natural caves and man-made constructions in temperate zones can provide stable shelters that are regularly and repeatedly used by various bat species. Bats roost in these areas seasonally and consequently they play an important role in the dispersal of microorganisms. According to published data and our results, bat guano could be an important source of bacteria; we are specifically looking at the prevalence of NTM in bat guano. In this study, the aim was the detection, quantification, and species identification of mycobacteria present in bat guano collected from caves as well as attics and roof structures of buildings where bats roost in different European countries.

\section{Materials and Methods}

A total of 281 guano samples (bat droppings older than $2 \mathrm{~h}$ ) from eight European countries (Bulgaria, Czech Republic, France, Hungary, Italy, Romania, Slovakia, and Slovenia) were collected and examined; 181 from caves located in all eight countries and 100 from attics and roof structures located only in the Czech Republic (Table 1 and Scheme 1). Most of the guano samples collected from caves came from hibernating Lesser Horseshoe Bats (Rhinolophus hipposideros) or Greater Mouse-eared Bats (Myotis myotis), the two species most commonly found in hibernating communities [48]. Whilst these samples were collected under colonies of these bat species, the presence of guano from other bat species could not be excluded (unpublished observation). Guano collected from attics roof structures originated from summer colonies of the female Greater Mouse-eared Bats (Myotis myotis) with offspring in different buildings such as post offices, elementary schools, chateaus, churches, old town halls, private and residential houses, and hotels (Table 1).

\subsection{Sample Collection}

Each guano sample was separately taken by sterile tongue depressor and put into a $200 \mathrm{~mL}$ sterile plastic bag. After collection, the samples in plastic bags were transported to the laboratory at $+6{ }^{\circ} \mathrm{C}$ where they were divided in to three parts for bacteriological analysis. Approximately $10 \mathrm{~g}$ of guano was transferred into a sterile disposable plastic container $(30 \mathrm{~mL})$ and was kept at $+6^{\circ} \mathrm{C}$ for up to 1 week before bacteriological analysis. Approximately $0.1 \mathrm{~g}$ of guano was put in a microfuge tube before DNA isolation, which was either completed immediately or stored at $-20^{\circ} \mathrm{C}$ until used. The remainder of the guano sample was dried for geochemical analysis [43].

\subsection{Bacteriological Methods for Mycobacteria Detection and Identification}

All 281 samples were examined for the presence of mycobacteria by direct microscopy after Ziehl-Neelsen (ZN) staining and culture examination. From 149 randomly selected guano samples, mycobacterial DNA was isolated for direct identification and quantification by qPCR (Table 2 ).

\subsubsection{ZN Staining}

Before culture examination, guano samples were stained according to $\mathrm{ZN}$ and examined by light microscopy for the presence of acid-fast bacteria (AFB). At least 200 fields of view were examined in each guano sample [49]. The amount of AFB was evaluated as follows: negative (No AFB), + (sporadic presence of AFB),++ (a small but significant amount of AFB present), +++ (too numerous to count $=$ TNTC AFB) as it is shown in Table 2. 
Table 1. Examined guano samples from caves and attics from nine countries.

\begin{tabular}{cccccccccc}
\hline Country & \multicolumn{3}{c}{ Locality Nos. } & & \multicolumn{5}{c}{ Bat Guano Sample Nos. } \\
\hline $\begin{array}{c}\text { Of } \\
\text { Origin }\end{array}$ & Total & Caves & Attics & Total & $\begin{array}{c}\text { Cult }+ \\
\text { ve (\%) }\end{array}$ & Caves & $\begin{array}{c}\text { Cult + } \\
\text { ve (\%) }\end{array}$ & $\begin{array}{c}\text { Attics } \\
\text { Cult + } \\
\text { ve (\%) }\end{array}$ \\
\hline Bulgaria & $4^{1}$ & $4^{1}$ & 0 & 6 & $5(83.3)$ & 6 & $5(83.3)$ & 0 & $0(0)$ \\
Czech R. & 96 & $27^{2}$ & $69^{3}$ & 210 & $52(24.8)$ & 110 & $36(32.7)$ & 100 & $16(16.0)$ \\
France & $3^{4}$ & $3^{4}$ & 0 & 4 & $1(25.0)$ & 4 & $1(25.0)$ & 0 & $0(0)$ \\
Hungary & $3^{5}$ & $3^{5}$ & 0 & 9 & $1(11.1)$ & 9 & $1(11.1)$ & 0 & $0(0)$ \\
Italy & $1^{6}$ & $1^{6}$ & 0 & 2 & $1(50.0)$ & 2 & $1(50.0)$ & 0 & $0(0)$ \\
Romania & $4^{7}$ & $4^{7}$ & 0 & 10 & $6(60.0)$ & 10 & $6(60.0)$ & 0 & $0(0)$ \\
Slovakia & $10^{8}$ & $10^{8}$ & 0 & 34 & $7(20.1)$ & 34 & $7(20.1)$ & 0 & $0(0)$ \\
Slovenia & $4^{9}$ & $4^{9}$ & 0 & 6 & $1(16.7)$ & 6 & $1(16.7)$ & 0 & $0(0)$ \\
\hline Total & 125 & 56 & 69 & 281 & $74(26.3)$ & 181 & $58(32.0)$ & 100 & $16(16.0)$ \\
\hline
\end{tabular}

Table interpretation. ${ }^{1}$ Bulgaria: Lovech Region, Devetashka Cave, Sofia Province, Temnata Dupka Cave, Cevdarska Cave and Vidin Province, Kozarnika Cave; ${ }^{2}$ Czech Republic, Caves in Moravian Karst: Amaterska Cave, Part Stara Amaterska Cave, Balcarka Cave, Barova Cave, Byci skala Cave System (Svozilova Cave, Dragonback Ridge, Pagan Chimney, and Southern Branch), Cisarska (Eniodis) Cave, Hedvabna Sinkhole Cave, Jestrabka Cave, Katerinska Cave, Kralova Cave, Marianska Cave, Mastny Flek Cave, Mine No. 4 in Josefovske Valley, Nad Svycarnou Cave, Nova Rasovna Cave, Ochozska Cave, Pekarna Cave, Pod Hradem Cave, Ricka I Karst Resurgence, Rudicke propadani Cave System, Slloupsko-Sosuvske Caverns, Sloupsko-Sosuvske Caves, Stara Dratenicka Cave, Suchozlebska Zazdena Cave, and Vypustek Cave; ${ }^{3}$ Czech Republic, Attics: Bitov (castle), Bohdalice (post office building), Bohuslavice (church), Brno Lisen (elementary school), Bucovice (chateau), Budiskovice (chateau, Institute for social care), Bystrice pod Hostynem (church of St. Jilii), Cvikov (old Towm Hall), Cermna (church), Cesky Dub (elementary art school), Dolany (church), Dolni Zalezly (private house), Doubravnik (church), Duba (residential house Ceskolipska), Hanusovice (church St. Mikulase), Harasov (hotel), Horni Police (church), Hostejn (church), Chribska (church), Chudobin (church), Jenisovice (church), Jevisovice (Old Chateau), Jicineves (church), Jilove u Prahy (church), Jitrava (church), Kerhartice (elementary school), Kopidlno (former cinema), Krnsko (church), Kvitkov (municipal office), Ledce (hunting lodge), Lesonice $u$ Moravskych Budejovic (chateau), Liban (church), Liblin (cellar of the former brewery), Libun (church), Lobendava (church), Loukov u Semil (church), Lysice (church), Manetin (church St. J. Krtitele), Milesov (chateau), Mladonov (church St. Mikulase), Moravicany (church St. J. Krtitele), Moravsky Karlov (church), Mostkov (monastery-former cowshed), Nova Hradecna (church St. Vavrince), Nove Losiny (church St. Isidora), Ohnic (residential houses Nos. 39 and 19), Otaslavice (church), Plumlov (Upper chateau), Povrly (residential house Drazni 8/201), Prachatice (church St. Jakuba), Racice (church), Racice (chateau), Radnice (church), Rajnochovice (parish church), Raskov (church), Ruda nad Moravou (chateau), Rudnik (church), Rusava-Horansko (church), Senozaty (church), Snedovice (residential house No. 91), Sobotin (Diaconia, building No. II), Trebivlice (Chateau-elementary school), Turnov (church St. Mikulase), Ustek (church), Velka Bystrice (church), Veselicko (chateau, Children's educational institute), Vysoke Veseli (residential house), Znojmo (church St. Krize) and Zeleznice (church); ${ }^{4}$ France: The Bramabiau Cave, Lozere, The Baoumas Cave, and Millau, Caoussou II; ${ }^{5}$ Hungary: Aggtelek Karst, The Almási Cave, The Széki cave, and The Vecsembükki Cave; ${ }^{6}$ Italy: Sicily, Risorgenza di Monte Conca; ${ }^{7}$ Romania: The Gaura cu Muscă Cave, The Plopa Cave, The Ponicova Cave, and Ciucaru Mare-Stole; ${ }^{8}$ Slovakia: Slovakian Karst, Bezodna Ladnica Cave, Brectanova Abyss, Cave in Hradisko, Hacavska Cave, Hrusovska Cave, Jasovska Cave, Liscia Diera Cave, Psia diera Cave, Silicka Ladnica Cave, Viola I Mining Gallery; ${ }^{9}$ Slovenia: The Globocnina Cave, The Medvedjak Cave, The Skocjan Caves, and The Velika Sprincica Cave.

\subsubsection{Culture Examination}

Guano samples were decontaminated using $4 \% \mathrm{NaOH}$ and the $1 \%$ surfactant tetradecyltrimethylammonium bromide (TDAB; Duchefa Biochemie B.V., Haarlem, The Netherlands). The pre-treatment consisted of complete homogenization of the sample (5 to $10 \mathrm{~g}$ ) with $10 \mathrm{~mL}$ of distilled water and shaking at 300 oscillations/min for $30 \mathrm{~min}$. After centrifugation at $500 \mathrm{rpm}$ (revolutions per minute) for $10 \mathrm{~min}$, the supernatant was transferred to a new container and centrifuged at $4300 \mathrm{rpm}$ for $20 \mathrm{~min}$. A total of $10 \mathrm{~mL}$ of decontamination solution was added to the sediment and the sample was homogenized by vortexing for $1 \mathrm{~min}$ and shaking for $10 \mathrm{~min}$. After centrifugation (4300 rpm for $20 \mathrm{~min}$ ), supernatant was poured out, the pellet was neutralized by adding $15 \mathrm{~mL}$ of distilled water, and the pellet was vortexed. After final centrifugation (4300 rpm for $20 \mathrm{~min}$ ) and pouring of water, the pellet was resuspended in $2.5 \mathrm{~mL}$ of saline. Thus, processed samples were inoculated onto four Löwenstein-Jensen media slants culture media, which were incubated at 30 and $37^{\circ} \mathrm{C}$ for 12 weeks [50]. In each sample, culture positivity was evaluated according to the number of colony forming units (CFU's). Different types of visible single CFU in one sample were individually subcultured for further identification. 


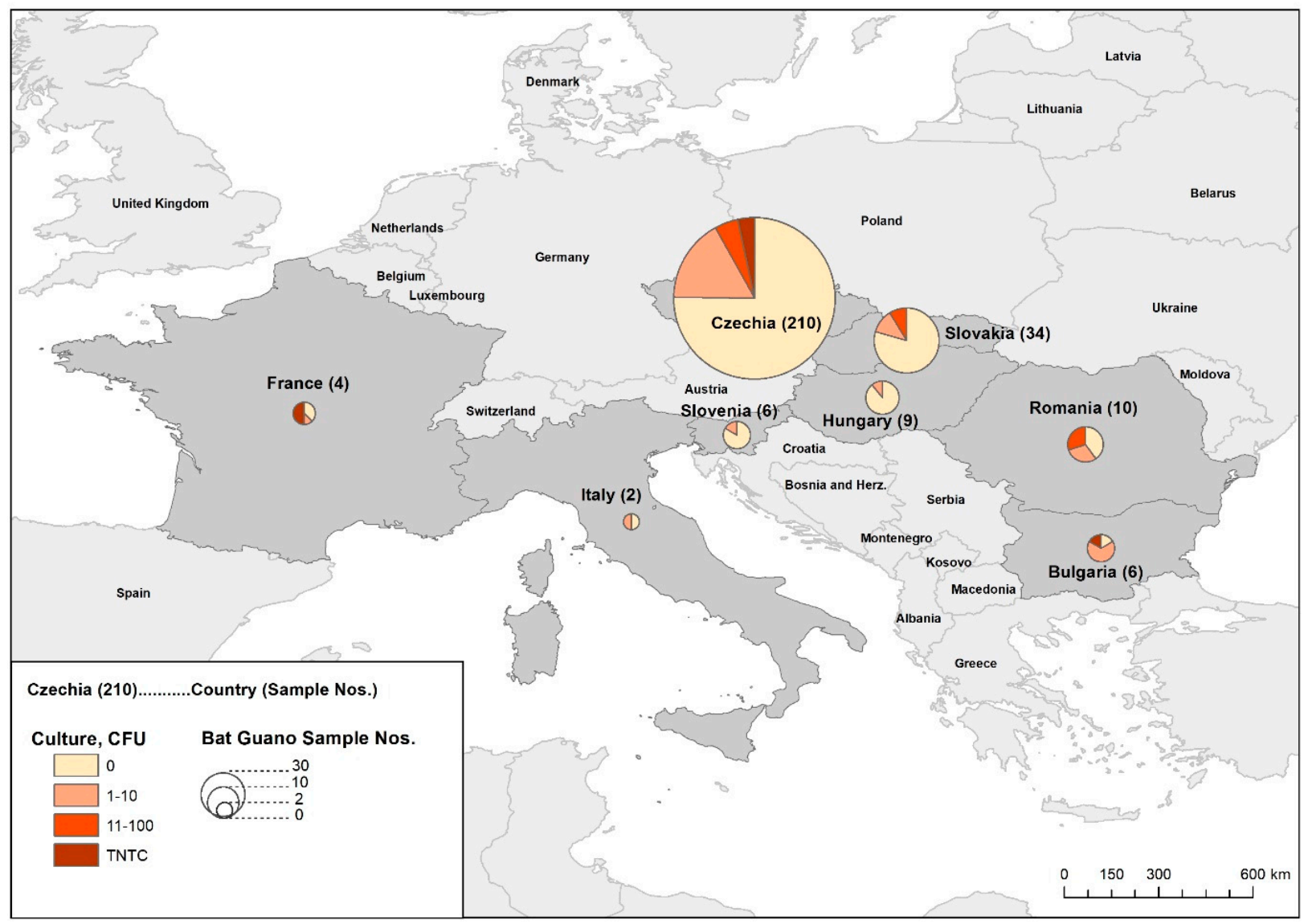

Scheme 1. Origin of examined guano samples. Map interpretation. Culture = positive results; $\mathrm{CFU}=$ colony forming units.

Table 2. Mycobacteria detection in caves' and attics' guano samples.

\begin{tabular}{|c|c|c|c|c|c|c|c|c|c|c|c|c|}
\hline \multicolumn{4}{|c|}{ Mycobacteria Detection } & \multicolumn{5}{|c|}{ Caves' Guano } & \multicolumn{4}{|c|}{ Attics' Guano } \\
\hline \multirow[t]{2}{*}{ ZN } & \multirow{2}{*}{$\begin{array}{l}\text { Culture } \\
\text { (CFU) }\end{array}$} & \multirow{2}{*}{$\begin{array}{c}\text { Sample } \\
\text { Nos. }\end{array}$} & \multirow[t]{2}{*}{ qPCR } & \multirow[t]{2}{*}{ qPCR+ } & \multicolumn{4}{|c|}{ No. of } & \multicolumn{4}{|c|}{ No. of } \\
\hline & & & & & Samples & Isolates * & qPCR & qPCR+ & Samples & Isolates * & qPCR & qPCR+ \\
\hline \multirow{6}{*}{-} & 0 & 134 & 73 & 56 & 59 & 0 & 12 & 8 & 75 & 0 & 61 & 48 \\
\hline & $1-10$ & 16 & 10 & 9 & 12 & 16 & 7 & 6 & 4 & 5 & 3 & 3 \\
\hline & $11-100$ & 3 & 3 & 3 & 3 & 3 & 3 & 3 & 0 & 0 & 0 & 0 \\
\hline & TNTC & 1 & 1 & 1 & 1 & 1 & 1 & 1 & 0 & 0 & 0 & 0 \\
\hline & Subtotal & 154 & 87 & 69 & 75 & 20 & 23 & 18 & 79 & 5 & 64 & 51 \\
\hline & $\%$ & 100 & & & 48.7 & & & & 51.3 & & & \\
\hline \multirow{7}{*}{+} & 0 & 73 & 26 & 23 & 64 & 0 & 20 & 17 & 9 & 0 & 6 & 6 \\
\hline & $1-10$ & 34 & 22 & 21 & 22 & 27 & 10 & 9 & 12 & 12 & 12 & 12 \\
\hline & $11-100$ & 13 & 8 & 8 & 13 & 15 & 8 & 8 & 0 & 0 & 0 & 0 \\
\hline & TNTC & 7 & 6 & 6 & 7 & 11 & 6 & 6 & 0 & 0 & 0 & 0 \\
\hline & Subtotal & 127 & 62 & 58 & 106 & 53 & 44 & 40 & 21 & 12 & 18 & 18 \\
\hline & $\%$ & 100 & & & 83.5 & & & & 16.5 & & & \\
\hline & 0 & 207 & 99 & 79 & 123 & 0 & 32 & 25 & 84 & 0 & 67 & 54 \\
\hline \multirow{5}{*}{$\begin{array}{c}\text { All } \\
\text { ZN } \\
\text { Results }\end{array}$} & 1-10 & 50 & 32 & 30 & 34 & 43 & 17 & 15 & 16 & 17 & 15 & 15 \\
\hline & 11-100 & 16 & 11 & 11 & 16 & 18 & 11 & 11 & 0 & 0 & 0 & 0 \\
\hline & TNTC & 8 & 7 & 7 & 8 & 12 & 7 & 7 & 0 & 0 & 0 & 0 \\
\hline & Subtotal & 281 & 149 & 127 & 181 & 73 & 67 & 58 & 100 & 17 & 82 & 69 \\
\hline & $\%$ & 100 & 53.0 & & 64.4 & & & & 35.6 & & & \\
\hline
\end{tabular}

Table interpretation. ZN = microscopy examination after the Ziehl-Neelsen staining in at least 200 fields; - = negative examination; + sporadic acid-fast bacteria (AFB) detection; $\mathrm{CFU}=$ colony forming units; No. of examined guano samples by qPCR = quantitative PCR test;

* in some samples, more isolates of different mycobacterial sp. and ssp. were detected. 


\subsubsection{Isolates Identification}

After macroscopic and microscopic evaluation, the isolates were identified mainly by molecular biological methods. Genotype Mycobacterium CM, AS, and NTM/DR kits (Qiagene, Hain Lifescience, Nehren, Germany) were used for basic identification. Detailed identification of mycobacterial sp. and ssp. not included in above-mentioned commercial kits was performed by sequencing and BLAST analysis [50]. M. avium ssp. avium was further identified by the PCR method for the detection of the specific IS901 amplicon and M. avium ssp. hominissuis for the specific IS1245 amplicon [51].

\subsection{Molecular Methods for Mycobacteria Quantification}

In parallel with culture and microscopic examinations, detection and quantification of mycobacterial DNA was performed. Z-Path-Mycobacterium_spp detection kit for Mycobacterium (Primerdesign Ltd., Eastleigh, UK) was used and E.Z.N.A. ${ }^{\circledR}$ Soil DNA Kit (Omega Bio-tek, Norcross, GA, USA) was used to isolate mycobacterial DNA according to the manufacturer's instructions. DNA isolation was performed from a $1 \mathrm{~mL}$ homogenized and decontaminated guano sample (described in Section 2.2.2). Amplification and evaluation were performed on a CFX96 real-time PCR detection system (Bio-Rad Laboratories, Hercules, CA, USA) using the following thermocycler conditions: 50 cycles at $95^{\circ} \mathrm{C}$ for $10 \mathrm{~s}$ and at $60^{\circ} \mathrm{C}$ for $60 \mathrm{~s}$. Quantification of viable mycobacteria was performed by comparison with a number of standards using CFX Manager Software (Bio-Rad Laboratories, Hercules, CA, USA). Quantification is expressed in copies of a specific section of DNA per $1 \mathrm{~mol}$ of template [50].

\subsection{Physico-Chemical Analyses}

The samples of guano (about $100 \mathrm{~g}$ ) were transported for physico-chemical analyses on ice in a cooler and analysed immediately after sampling. Samples were dried at $60^{\circ} \mathrm{C}$ until a constant weight was achieved, ISO methods were employed for the determination of $\mathrm{pH}$, Electrical Conductivity (EC), Oxidation-Reduction Potential (ORP), Total Organic Carbon (TOC), and Total Inorganic Carbon (TIC). $\mathrm{pH}$ and EC were measured in aqueous extracts. A WTW InoLab Multi 720 tool with a SenTix 41 electrode (WTW Ltd., Czech Republic) was used for $\mathrm{pH}$ measurements. For EC measurements, guano aliquots were mixed with distilled water (1:5), shaken for $30 \mathrm{~min}$, and measured on a multimeter WTW Multi 3320 (BDL Czech Republic s.r.o., Turnov, Czech Republic) with a TetraCon 325 electrode (Xylem Analytics Germany GmbH, Weilheim, Germany).

TOC and TIC in the guano samples were measured using a SoliTOC Cube analyzer by temperature-dependent differentiation of Total Carbon (TC) into TOC400, ROC, and TIC900 to determine the content of TOC. The method consisted of temperature ramping from $400-900{ }^{\circ} \mathrm{C}$ at a constant heat rate $(70 \mathrm{~K} / \mathrm{min})$ in oxygenated air for TOC400 and TIC900 determination with a subsequent switch to a non-oxygenated air $\left(\mathrm{N}_{2}\right.$ alone) for accurate ROC determination. The temperature hold times applied for individual $\mathrm{C}$ fraction determinations were 230, 150, and 120 s, respectively, and were DIN 19539-compliant. The TOC was calculated from the sum of TOC400 and ROC. All C fractions were measured using a high-sensitivity infrared sensor. The weight of measured samples was $1 \pm 0.15 \mathrm{~g}$.

\subsection{Statistical Analysis}

Data analysis was performed using statistical software Statistica 13.2 (StatSoft Inc., Tulsa, OK, USA) and StatXact 12.0 (Cytel Inc., Waltham, MA, USA). $p$-values less than 0.05 were considered statistically significant. $\mathrm{ZN}$ microscopy and culture results could be considered as ordinal variables (ZN: negative $<$ AFB $+<\mathrm{AFB}++<\mathrm{AFB}+++$; culture examination: $0=$ negative $<1-10<11-100<$ TNTC). Spearman's correlation coefficient was used to evaluate the correlations of the results of all three methods [52]. The associations between the results of ZN microscopy, results of culture examination, or results of qPCR and the origin of the guano sample were assessed using the Mann-Whitney test; $p$-values were calculated from the exact (not from asymptotic distribution). The association between 
the quantitative qPCR result (positive/negative) and the origin of the sample was assessed using Fisher's exact test. The alpha-diversity of mycobacterial sp. and ssp. isolated from guano samples collected from caves and attics was assessed using the Shannon-Wiener H index of diversity [53]. The Hutcheson test was used to compare $\mathrm{H}$ indexes according to the origin of the samples. The beta-diversity of mycobacterial sp. and ssp. isolated from guano samples was assessed by paired PERMANOVA (Bray-Curtis dissimilarity, 9999 permutations).

\section{Results}

\subsection{Microscopically, Culture and $q P C R$ Examinations}

$\mathrm{ZN}$ microscopy was positive for mycobacteria (AFB +, AFB ++ and AFB +++) in 127 (45.2\%) guano samples. A total of $74(16.3 \%)$ samples were culture positive with varying numbers of $\mathrm{CFU}$ per sample ranging from a single CFU to too many CFU's to count (TNTC; Table 2). All culturable mycobacteria belonged to risk groups 1 and 2. Mycobacteria were detected in guano samples originating from caves in all 8 countries sampled (Table 1 and Figure 1). Mycobacterial DNA was detected by qPCR in 127 (85.2\%) guano samples with $51(76.1 \%)$ and $69(84.1 \%)$ detected in guano collected from caves and attics, respectively (Table 2).

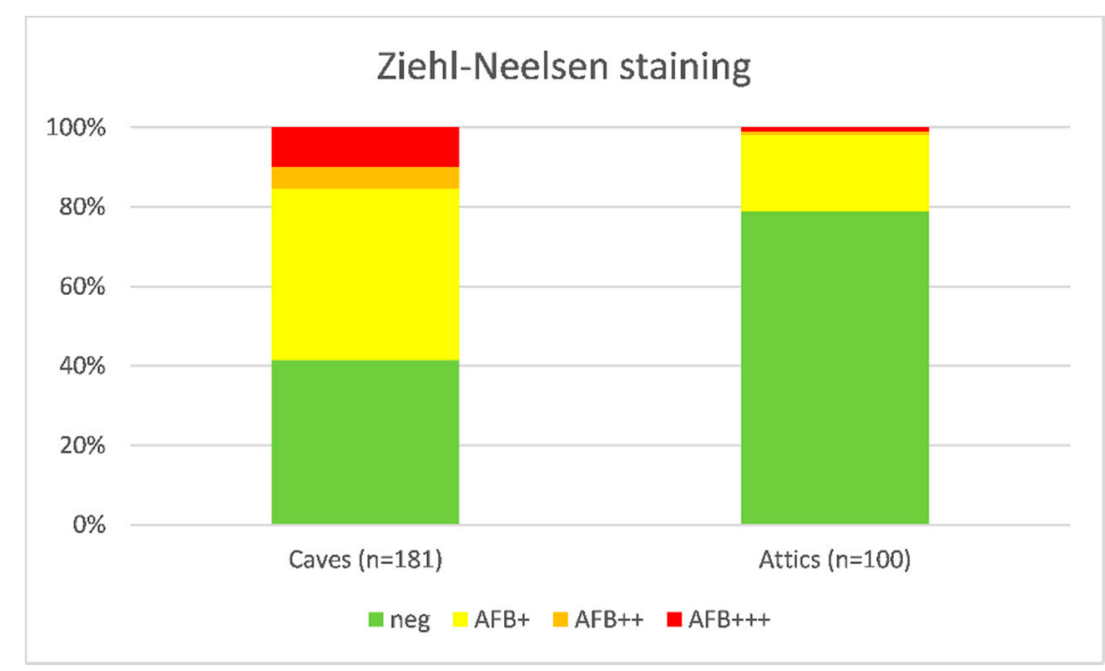

Figure 1. Bat guano origin and $\mathrm{ZN}$ microscopy results. Figure interpretation. $\mathrm{ZN}=$ microscopy examination after the Ziehl-Neelsen staining in at least 200 fields [43]; negative = negative examination; + sporadic acid-fast bacteria (AFB) detection; ++ = few AFB present in each field; $+++=$ too numerous to count (TNTC) of AFB in each field.

The strength of association based on size of Spearman's correlation coefficients between ZN microscopy and culture examination can be considered moderate to substantial. The correlation between both $\mathrm{ZN}$ microscopy and culture examination with qPCR detection can be considered substantial to very strong. All correlations are positive, which indicates a consistent increasing trend in all used methods for mycobacteria detection (Table 3).

Table 3. Spearman's correlation coefficients for three methods of mycobacteria detection.

\begin{tabular}{cccc}
\hline Detection Method & ZN Microscopy & Culture Examination & qPCR \\
\hline ZN microscopy & & 0.4298 & 0.5809 \\
Culture examination & 0.4298 & & 0.6139 \\
qPCR & 0.5809 & 0.6139 &
\end{tabular}

Table interpretation. ZN = microscopy examination after the Ziehl-Neelsen staining in at least 200 fields [43]; qPCR $=$ quantitative PCR test. 
The proportion of samples with negative $\mathrm{ZN}$ microscopy examination in bat guano collected from attics was almost double that in bat guano collected from caves (Table 4 and Figure 1). The association was confirmed by Mann-Whitney test $(p<0.01 ; \mathrm{U}=12641)$.

Table 4. Bat guano origin and $\mathrm{ZN}$ microscopy results.

\begin{tabular}{cccccc}
\hline Guano Origin & Negative & AFB + & AFB ++ & AFB +++ & Total \\
\hline Caves & 75 & 78 & 10 & 18 & 181 \\
Attics & 79 & 19 & 1 & 1 & 100 \\
Total & 154 & 97 & 11 & 19 & 281 \\
\hline
\end{tabular}

Table interpretation. $\mathrm{ZN}=$ microscopy examination after the Ziehl-Neelsen staining in at least 200 fields negative $=$ negative examination; + sporadic acid-fast bacteria (AFB) detection; $++=$ few AFB present in each field; $+++=$ too numerous to count (TNTC) of AFB in each field.

The proportion of culture-negative guano samples collected from attics was significantly higher than this proportion of culture-positive guano samples collected from caves ( $p<0.01 ; \mathrm{U}=10694$; Mann-Whitney test). No samples with CFU's > 10 were detected in attic-derived guano samples (Table 5 and Figure 2).

Table 5. Bat guano origin and culture examination results.

\begin{tabular}{cccccc}
\hline Guano Origin & $\mathbf{0 ~ C F U}$ & $\mathbf{1 - 1 0}$ CFU & $\mathbf{1 1 - 1 0 0 ~ C F U ~}$ & TNTC CFU & Total \\
\hline Caves & 123 & 34 & 16 & 8 & 181 \\
Attics & 84 & 16 & 0 & 0 & 100 \\
Total & 207 & 50 & 16 & 8 & 281 \\
\hline
\end{tabular}

Table interpretation. CFU = colony forming units; TNTC = too numerous to count.

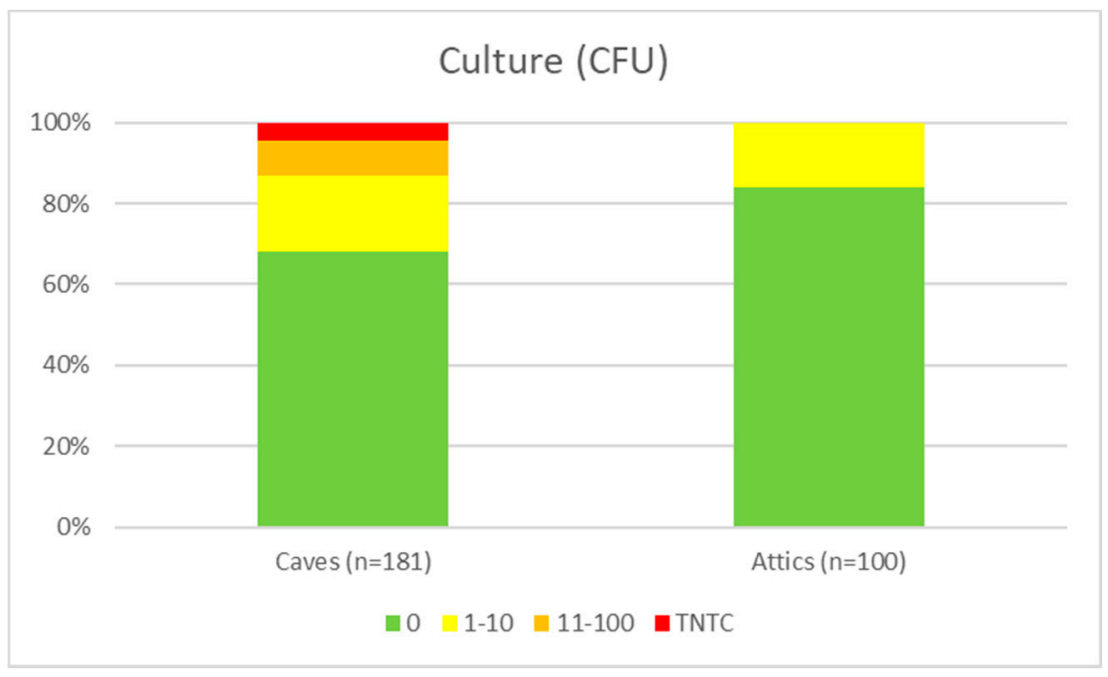

Figure 2. Bat guano origin and culture examination results. Figure interpretation. $\mathrm{CFU}=$ colony forming units; TNTC $=$ too numerous to count.

\subsection{Detected Mycobacterial Species and Subspecies Composition and Clinical Relevance}

A total of 19 NTM sp. and ssp. belonging to three groups and four complexes were isolated from bat guano samples (Table 6). All 19 NTM sp., ssp. and complex's were identified from guano samples from caves, in contrast, only three species (M. arupense, $M$. terrae, and M. fortuitum), one subspecies (M. avium ssp. hominissuis), and one complex ( $M$. terrae complex) were found in attic derived guano. The most common isolates from both types of bat guano were identified as $M$. fortuitum $(n=21)$ and M. avium ssp. hominissuis $(n=11)$. In concordance with this, NTM biodiversity members of $M$. fortuitum group $(n=24)$, $M$. terrae complex $(n=22)$, and M. avium complex $(n=14)$ were observed as most abundant in both types of guano samples. 
Table 6. Detected identified mycobacteria in relation to the complexes and groups.

\begin{tabular}{|c|c|c|c|c|c|}
\hline \multirow[t]{2}{*}{ Identification } & \multirow{2}{*}{$\begin{array}{c}\text { Risk } \\
\text { Group }^{1}\end{array}$} & \multirow{2}{*}{$\begin{array}{l}\text { Group or } \\
\text { Complex }\end{array}$} & \multicolumn{3}{|c|}{ No. of Bat Guano Isolates } \\
\hline & & & Total (\%) & Caves $(\%)$ & Attics (\%) \\
\hline M. abscessus ssp. bolletii & 2 & MCG & $1(1.1)$ & $1(1.4)$ & $0(0)$ \\
\hline M. algericum & 1 & MTC & $2(2.3)$ & $2(2.7)$ & $0(0)$ \\
\hline M. arupense & 2 & MTC & $5(5.6)$ & $3(4.1)$ & $2(12.5)$ \\
\hline M. avium ssp. avium & 2 & MAC & $3(3.4)$ & $3(4.1)$ & $0(0)$ \\
\hline M. avium ssp. hominissuis & 2 & MAC & $11(12.4)$ & $5(6.9)$ & $6(37.5)$ \\
\hline M. chelonae & 2 & MCG & $2(2.3)$ & $2(2.7)$ & $0(0)$ \\
\hline M. fortuitum & 2 & MFG & $21(23.6)$ & $19(26.0)$ & $2(12.5)$ \\
\hline M. gilvum & 1 & MVC & $2(2.3)$ & $2(2.7)$ & $0(0)$ \\
\hline M. hiberniae & 1 & MTC & $2(2.3)$ & $2(2.7)$ & $0(0)$ \\
\hline M. kumamotonense & 1 & MTC & $1(1.1)$ & $1(1.4)$ & $0(0)$ \\
\hline M. minnesotense & 1 & MTC & $1(1.1)$ & $1(1.4)$ & $0(0)$ \\
\hline M. mucogenicum & 2 & MMG & $1(1.1)$ & $1(1.4)$ & $0(0)$ \\
\hline M. nonchromogenicum & 2 & MTC & $1(1.1)$ & $1(1.4)$ & $0(0)$ \\
\hline M. peregrinum & 2 & MFG & $2(2.3)$ & $2(2.7)$ & $0(0)$ \\
\hline M. phlei & 1 & MSC & $2(2.3)$ & $2(2.7)$ & $0(0)$ \\
\hline M. septicum & 2 & MFG & $1(1.1)$ & $1(1.4)$ & $0(0)$ \\
\hline M. terrae complex & 1 & MTC & $5(5.6)$ & $4(5.5)$ & $1(6.3)$ \\
\hline M. terrae & 1 & MTC & $3(3.4)$ & $2(2.7)$ & $1(6.3)$ \\
\hline M. triviale & 1 & MTC & $2(2.3)$ & $2(2.7)$ & $0(0)$ \\
\hline M. sp. & NK & NK & $21(23.6)$ & $17(23.3)$ & $4(25.0)$ \\
\hline Risk Group 1 & 9 sp. and ssp. & & $20(22.5)$ & $18(24.6)$ & $2(12.5)$ \\
\hline Risk Group 2 & $10 \mathrm{sp}$. and ssp. & & $48(53.9)$ & $38(52.1)$ & $10(62.5)$ \\
\hline Risk Group NK & NK sp. and ssp. & & $21(23.6)$ & $17(23.3)$ & $4(25.0)$ \\
\hline \multirow[t]{8}{*}{ Subtotal } & 2 & MFG & $24(27.0)$ & $22(30.1)$ & $2(12.5)$ \\
\hline & 2 & MCG & $3(3.4)$ & $3(4.1)$ & 0 \\
\hline & 2 & MMG & 1 (1.1) & $1(1.4)$ & 0 \\
\hline & 2 & MAC & $14(15.7)$ & $8(11.0)$ & $6(37.5)$ \\
\hline & $1-2$ & MTC & $22(24.7)$ & $18(24.7)$ & $4(25.0)$ \\
\hline & 1 & MVC & $2(2.3)$ & $2(2.7)$ & 0 \\
\hline & 1 & MSC & $2(2.3)$ & $2(2.7)$ & 0 \\
\hline & NK & NK & $21(23.6)$ & $17(23.3)$ & $4(25.0)$ \\
\hline Total & & & 89 (100) & 73 (100) & $16(100)$ \\
\hline
\end{tabular}

Table interpretation. M. = Mycobacterium; sp. = species; ssp. = subspecies; MFG = M. fortuitum Group; MCG = M. chelonae Group; $\mathrm{MMG}=$ M. mucogenicum Group; MAC = M. avium Complex; MTC = M. terrae Complex; MVC = M. vaccae Complex; MSC = M. smegmatis Complex; NK = Not Known Mycobacterium sp.; in bold are sp., ssp. and complex isolated from both bat guano types (from caves and attics); $\mathrm{NK}=$ not known; ${ }^{1}$ Directive 2000/54/EC [45].

Concerning clinical relevance to humans and animals, 20 (22.5\%) isolates made up of $9 \mathrm{sp}$. and ssp. belonged to risk group 1 of biological agents and $48(53.9 \%)$ isolates from $10 \mathrm{sp}$. and ssp. belonged to risk group 2 of biological agents. None of the isolated mycobacterial species belonged to risk group 3 of biological agents, and $21(23.6 \%)$ isolates were not precisely identified (Table 6).

The alpha-diversity of NTM was statistically significantly higher for guano samples collected from caves than those from attics $\left(p<0.01 ; \mathrm{t}_{\mathrm{H}}=3.96 ; \mathrm{df}=23.45\right.$; Hutcheson $t$-test). Paired PERMANOVA testing the frequencies of individual NTM including NK (Not Known Mycobacterium sp.) showed statistically significantly higher sp. and ssp. abundance (beta-diversity) of NTM isolates in cave-derived bat guano samples $(p<0.01 ; \mathrm{F}=24.54$; Table 7).

\subsection{Mycobacteria Quantification by $q P C R$}

The proportions of mycobacteria positive and negative bat guano samples derived from caves or attics were similar. NTM were detected in $58(86.6 \%)$ bat guano samples collected from caves and in $69(84.2 \%)$ bat guano samples collected from attics (Table 8 ). 
An association between positive qPCR result and the origin of the sample could not be demonstrated ( $p>0.05$, Fisher's exact test).

Table 7. The alpha-diversity of NTM in caves' and attics' bat guano evaluated by Shannon-Wiener H index of diversity.

\begin{tabular}{ccccc}
\hline Guano Origin & $\begin{array}{c}\text { No. of NTM } \\
\text { Species without } \\
\text { NIM }\end{array}$ & No. of Isolates & $\begin{array}{c}\text { Shannon- } \\
\text { Wiener Index } \\
\mathbf{( H )}\end{array}$ & $\begin{array}{c}\text { 95\% Confidence } \\
\text { Interval of H } \\
\text { Index }\end{array}$ \\
\hline Caves & 19 & 56 & 2.47 & $2.16-2.77$ \\
Attics & 5 & 12 & 1.36 & $0.89-1.83$ \\
\hline
\end{tabular}

Table interpretation. CFU = colony forming units; TNTC = too numerous to count.

Table 8. Nontuberculous mycobacteria detection by qPCR in caves' and attics' bat guano samples.

\begin{tabular}{cccc}
\hline Guano Origin & Negative & Positive & Total \\
\hline Caves & 9 & 58 & 67 \\
Attics & 13 & 69 & 82 \\
Total & 22 & 127 & 149 \\
\hline
\end{tabular}

Table interpretation. $\mathrm{qPCR}=$ quantitative PCR test.

The geometric mean of $\mathrm{cp} / \mathrm{mL}$ DNA NTM detected by qPCRs in cave-derived bat guano samples was approximately 7 -fold higher than the geometric mean of $\mathrm{cp} / \mathrm{mL}$ DNA NTMs detected in guano samples derived from attics. The median qPCR-positive bat guano samples collected from caves was about 16-fold higher than the median positive of bat guano samples from attics; $95 \%$ confidence intervals of geometric means or medians did not overlap. The median qPCR values were statistically significantly higher in cavederived bat guano samples than those collected from attics $(p<0.01$; Mann-Whitney test; $\mathrm{U}=1276$ ). Thus, not only higher alpha- and beta-biodiversity was demonstrated in bat guano samples collected from caves, but also a higher proportion of positive microscopic findings after staining according to $\mathrm{ZN}$ and culture examination. In the case of qPCR detection and quantification, the proportions of guano samples positive for NTM detection did not differ statistically significantly. The levels of mycobacterial DNA (and by inference the amount of viable mycobacteria) detected in cave-derived bat guano samples were an order of magnitude higher than those collected from attics (Table 9 and Figure 3).

Table 9. Comparison of qPCR-positive (cp/mL DNA) values of NTM in caves' and attics' bat guano samples.

\begin{tabular}{ccc}
\hline Descriptive Statistics & Caves & Attics \\
\hline Number of values & 58 & 69 \\
Minimum (cp DNA) & 121 & 114 \\
Maximum (cp DNA) & $3,934,595$ & $2,245,950$ \\
Range (cp DNA) & $3,934,474,245,836$ \\
Median (cp DNA) & 72,382 & 4552 \\
Lower 95\% CI of median (cp DNA) & 18,871 & 2147 \\
Upper 95\% CI of median (cp DNA) & 225,009 & 11,146 \\
25\% Percentile (cp DNA) & 2285 & 647 \\
75\% Percentile (cp DNA) & 560,751 & 22,566 \\
Mean (cp DNA) & 517,812 & 140,662 \\
Std. Deviation (cp DNA) & 953,687 & 385,698 \\
Std. Error of Mean (cp DNA) & 125,225 & 46,433 \\
Lower 95\% CI of mean (cp DNA) & 267,053 & 48,008 \\
Upper 95\% CI of mean (cp DNA) & 768,572 & 233,317 \\
Geometric mean (cp DNA) & 42,492 & 6109 \\
Lower 95\% CI of geo. mean (cp DNA) & 18,898 & 3225 \\
Upper 95\% CI of geo. mean (cp DNA) & 95,543 & 11,574 \\
\hline
\end{tabular}




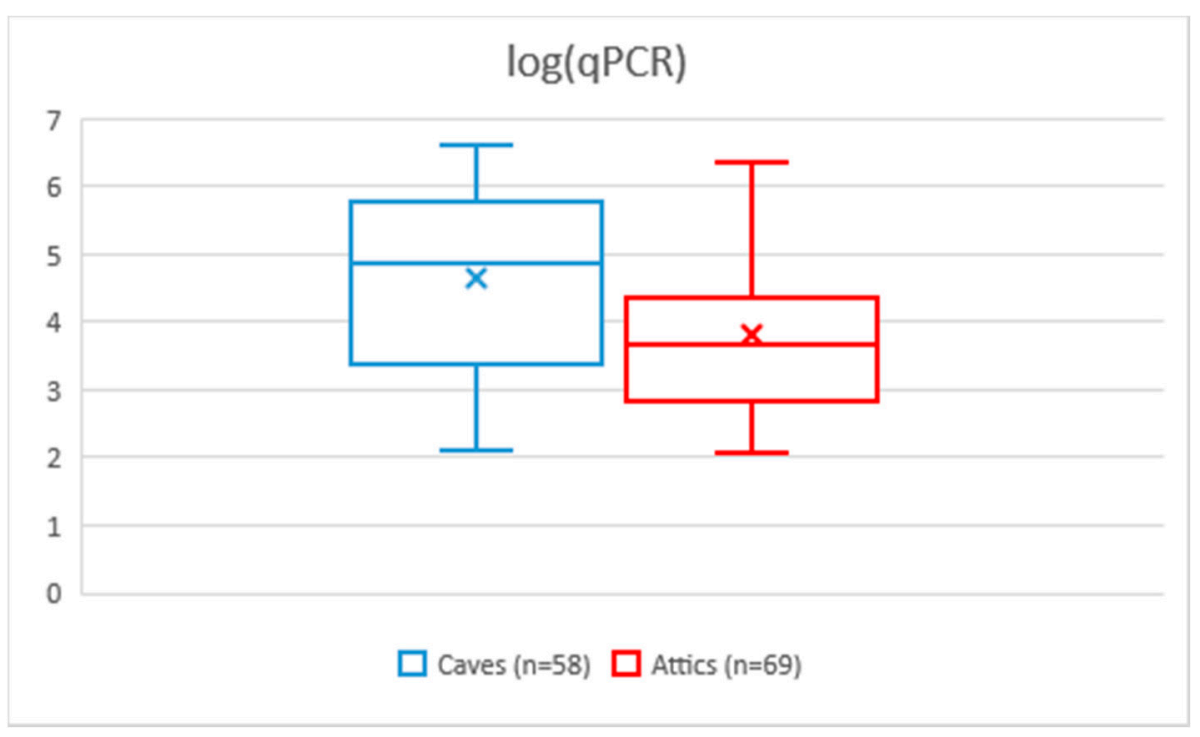

Figure 3. Box plot with qPCR values on a logarithmic scale. Figure interpretation. $\times$ corresponds to the geometric mean, the rectangle indicates the area between the upper and lower quartiles, and the horizontal line indicates the median and the vertical lines the range of values.

\subsection{Physico-Chemical Analyses of Bat Guano Samples}

Statistically highly significant differences ( $p<0.01$; Mann-Whitney test) between cave and attic-derived bat guano samples were demonstrated for the EC, TC, TOC, and TIC parameters. In contrast, no statistically significant difference ( $p>0.05$; Mann-Whitney test) was found for $\mathrm{pH}$ and ORP (Table 10 and Figure 4).

Table 10. Physico-chemical parameters of bat guano samples.

\begin{tabular}{|c|c|c|c|c|c|c|c|c|c|c|c|c|}
\hline \multirow{2}{*}{$\begin{array}{c}\text { Descriptive } \\
\text { Statistics }\end{array}$} & \multicolumn{2}{|c|}{$\mathrm{pH}$} & \multicolumn{2}{|c|}{ EC } & \multicolumn{2}{|c|}{ ORP } & \multicolumn{2}{|c|}{ TC } & \multicolumn{2}{|c|}{ TOC } & \multicolumn{2}{|c|}{ TIC } \\
\hline & Caves & Attics & Caves & Attics & Caves & Attics & Caves & Attics & Caves & Attics & Caves & Attics \\
\hline $\mathrm{n}$ & 45 & 71 & 43 & 71 & 38 & 62 & 38 & 69 & 40 & 69 & 40 & 69 \\
\hline Minimum & 4.58 & 5.24 & 2.13 & 209.50 & 110.30 & 218.00 & 0.00 & 24.98 & 0.00 & 24.98 & 0.00 & 0.15 \\
\hline Maximum & 8.54 & 9.06 & 7620.00 & 6350.00 & 424.60 & 370.20 & 68.25 & 97.05 & 50.55 & 93.65 & 18.00 & 23.90 \\
\hline Range & 3.96 & 3.82 & 7617.87 & 6140.50 & 314.30 & 152.20 & 68.25 & 72.07 & 50.55 & 68.67 & 18.00 & 23.75 \\
\hline Median & 7.01 & 6.60 & 303.00 & 2398.00 & 330.60 & 317.30 & 9.70 & 46.34 & 4.84 & 43.92 & 2.49 & 0.38 \\
\hline Lower $95 \% \mathrm{CI}^{1}$ & 5.91 & 6.50 & 197.80 & 1987.00 & 296.60 & 308.30 & 4.69 & 44.22 & 3.78 & 43.02 & 1.52 & 0.31 \\
\hline Upper $95 \% \mathrm{CI}^{1}$ & 7.39 & 6.68 & 487.00 & 2700.00 & 364.30 & 331.00 & 11.53 & 47.68 & 13.84 & 45.33 & 4.45 & 0.41 \\
\hline 25\% Percentile & 5.61 & 6.36 & 159.80 & 1792.00 & 273.45 & 297.05 & 4.32 & 43.09 & 3.14 & 41.57 & 0.81 & 0.26 \\
\hline $75 \%$ Percentile & 7.47 & 6.81 & 864.00 & 3494.00 & 367.83 & 336.48 & 21.60 & 51.03 & 18.23 & 46.73 & 5.80 & 0.52 \\
\hline Mean & 6.68 & 6.58 & 719.24 & 2629.82 & 319.55 & 314.73 & 16.54 & 52.23 & 12.31 & 46.48 & 4.47 & 1.21 \\
\hline Std. Deviation & 1.12 & 0.53 & 1233.26 & 1237.86 & 70.90 & 30.35 & 18.46 & 16.21 & 14.18 & 12.19 & 5.12 & 3.40 \\
\hline SEM & 0.17 & 0.06 & 188.07 & 146.91 & 11.50 & 3.85 & 3.00 & 1.95 & 2.24 & 1.47 & 0.81 & 0.41 \\
\hline Lower $95 \% \mathrm{CI}^{2}$ & 6.35 & 6.45 & 339.70 & 2336.83 & 296.25 & 307.03 & 10.47 & 48.33 & 7.77 & 43.55 & 2.84 & 0.40 \\
\hline Upper $95 \% \mathrm{CI}^{2}$ & 7.02 & 6.70 & 1098.78 & 2922.82 & 342.86 & 322.44 & 22.61 & 56.12 & 16.84 & 49.41 & 6.11 & 2.03 \\
\hline$p$-value ${ }^{3}$ & \multicolumn{2}{|c|}{$p>0.05$} & \multicolumn{2}{|c|}{$p<0.01$} & \multicolumn{2}{|c|}{$p>0.05$} & \multicolumn{2}{|c|}{$p<0.01$} & \multicolumn{2}{|c|}{$p<0.01$} & \multicolumn{2}{|c|}{$p<0.01$} \\
\hline
\end{tabular}

Table interpretation. EC = Electrical Conductivity $(\mu \mathrm{S} / \mathrm{cm}) ; \mathrm{ORP}=$ Oxidation-Reduction Potential $\left(\mathrm{mV}_{\mathrm{H}}\right)$; $\mathrm{TC}=$ Total Carbon $(\%) ;$ TOC = Total Organic Carbon (\%); TIC = Total Inorganic Carbon (\%); $\mathrm{n}=$ Number of examined samples; $\mathrm{CI}=\mathrm{Confidence} \mathrm{Interval;}$ SEM = Standard Error of Mean; ${ }^{1}$ Lower $/$ Upper 95\% CI of median; ${ }^{2}$ Lower/Upper 95\% CI of mean; ${ }^{3}$ Mann-Whitney test $p$-value. 


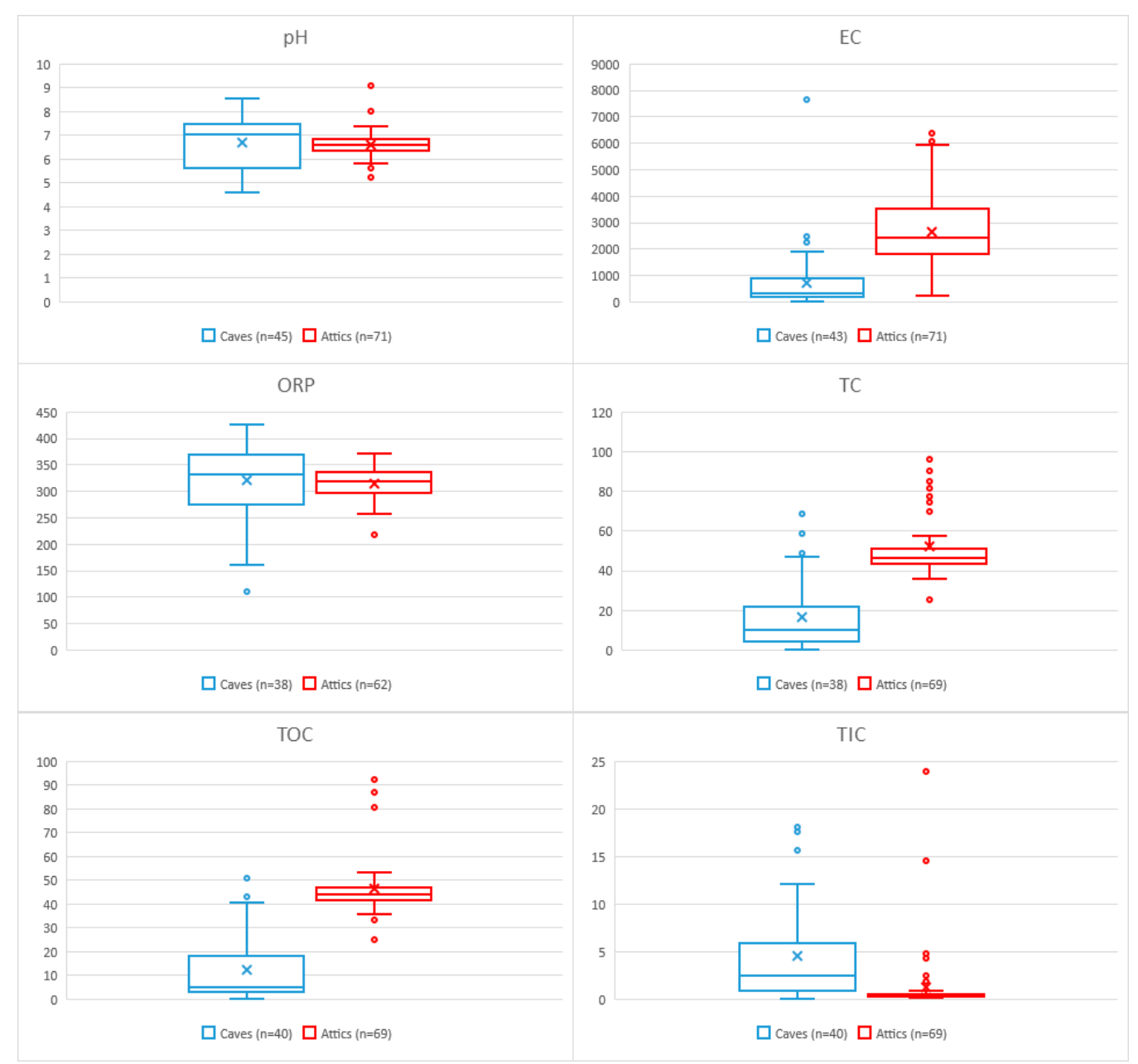

Figure 4. Box plot with Physico-chemical parameters of bat guano samples. Figure interpretation. $\times$ corresponds to the arithmetic mean; the rectangle indicates the area between the upper and lower quartiles; the horizontal line indicates the median, and the vertical lines plus points (outlier values) indicate the range of values; $\mathrm{EC}=$ Electrical Conductivity $(\mu \mathrm{S} / \mathrm{cm}) ; \mathrm{ORP}=$ Oxidation-Reduction Potential $\left(\mathrm{mV}_{\mathrm{H}}\right) ; \mathrm{TC}=$ Total Carbon $(\%) ; \mathrm{TOC}=$ Total Organic Carbon $(\%)$; TIC = Total Inorganic Carbon (\%); $\mathrm{n}=$ Number of examined samples.

\section{Discussion}

NTM were cultured from $32 \%$ of bat guano samples collected from different karst systems in Bulgaria, the Czech Republic, France, Hungary, Italy, Romania, Slovakia, and Slovenia (Table 1). These results correlate with finding from our previous study [43] and bat guano studies conducted in other countries including India [37-39], the Philippines [40], and Finland [16].

In this study, guano was mainly collected from caves where Horseshoe Bats (Rhinolophus spp. specifically, Rhinolophus hipposideros in the Czech Republic and Slovakia, and Rhinolophus ferrumequinum and middle sized Rhinolophus species in other studied European countries) were hibernating (unpublished observations). Colonies of Greater Mouse-eared Bat (Myotis myotis) were less commonly observed hibernating in caves in Czech localities; despite this, a number of guano samples from this species were collected from caves from this species. To complete the picture regarding the prevalence of mycobacteria in bat guano from different roosting environments, attics and other roof structures with roosting female colonies were visited. Specifically, colonies of female Greater Mouse-eared Bats (Myotis myotis) were found in attics roosting and giving birth during the summer season. Guano from such colonies was collected (Table 1). Dust in these spaces could also be an important reservoir of mycobacteria as well as a potential hazard for the dispersal of 
pollutants including metals [54,55]. Our results demonstrated culturable NTM in $16.0 \%$ of attic-derived guano samples (Table 1 ).

The detection of clinically relevant (risk group 2) species (i.e., $M$. arupense, $M$. avium ssp. hominissuis, and M. fortuitum) can pose a health risk for immuno-compromised people in contact with this bat guano found in attics (Table 6) [56]. In caves, bat guano was contaminated by NTM from risk group 2 such as M. abscessus ssp. bolletii, M. avium ssp. avium, M. chelonae, M. mucogenicum, M. nonchromogenicum, M. peregrinum, and M. septicum (Table 6). This data demonstrates that cave systems visited by bats could act as reservoirs of potentially pathogenic mycobacteria.

Concerning guano structure, the diet of the Lesser Horseshoe Bat consists primarily (over 50\%) on Lepidoptera and Dipteran insects [57,58]. Similarly, the diet of the larger species of Rhinolophus genus [59] consists mostly of moths (Lepidoptera), although a ground gleaning strategy has also been observed [60]. However, the Greater Mouse-eared Bat (Myotis myotis) is almost exclusively a surface gleaner, foraging for flightless insects, esp. carabid beetles, crickets, and spiders [61,62]. Insectivorous bats digest chitin in the stomach using acidic mammalian chitinase [63]. However, not all chitinous parts of the body of invertebrates are digested; debris of legs, wings, feelers, rafters of beetles were observed in guano by the naked eye (unpublished observations). Currently, bat guano is considered as a new and attractive source of chitin and chitosan for cosmetics, pharmacy, and medicine etc. [64].

Zingue and colleagues demonstrated that $M$. ulcerans reservoirs are connected with chitin sources around paddy fields and swampy areas [65]. Chitin may be an important nutrient source for this mycobacterial species. The addition of chitin to media purportedly improved culture examination of $M$. ulcerans by enhancing mycobacterial growth and contributing to the maintenance of an acidic $\mathrm{pH}[66,67]$. Species of Genus Mycobacterium play an important role in decomposition of organic waste in the environment; along with fungi, they are able to decompose materials such as polysaccharides (chitin, cellulose, etc.), lignin, and others. A lot of known enzymes involved in chitin and cellulose degradation are classified in the members of the Mycobacterium genus [36,68]. This information about the metabolic abilities of members of family Mycobacteriaceae allows interpretation of the abundant NTM species composition in guano isolated from cave and attic-derived guano (Table 6). Such NTM species spectrum is new information predicting an important role of NTM in bat guano degradation.

Currently, it is not clear as to how bats are exposed to mycobacteria. The most likely route of exposure is from the ingestion of non-vertebrates carrying mycobacteria. In previous studies, we demonstrated NTM could be cultured from the different non-vertebrates. $M$. avium ssp. avium, $M$. avium ssp. hominissuis, $M$. avium ssp. paratuberculosis, $M$. avium complex, M. chelonae, M. fortuitum, M. phlei, M. scrofulaceum, and M. sp. were isolated from adults of Order Diptera (families with percentages of culture positivity: Calliphoridae $=3.9 \%$, Drosophylidae $=12.5 \%$, Muscidae $=6.4 \%$, Scatophagidae $=8.6 \%$, and Syrphidae $=2.0 \%$ ). $M$. avium ssp. hominissuis, M. avium ssp. paratuberculosis, M. scrofulaceum, M. gastri, M. terrae, M. abscessus, and M. sp. were isolated from Order Opisthopora (specifically individuals from the family Lumbricidae; culture positivity $=8.2 \%$ ). From adult spiders and spiders webs of Order Araneae (culture positivity $=10.1 \%$,), M. avium ssp. avium, M. avium ssp. hominissuis, $M$. avium ssp. paratuberculosis, M. avium complex, M. fortuitum, M. chelonae, $M$. triviale, M. xenopi, and M. sp. were isolated. M. avium ssp. avium, M. avium ssp. hominissuis, and $M$. avium ssp. paratuberculosis were back isolated from developing stages, and imagoes of Order Coleoptera, family Tenebrionidae were fed on experimentally infected bran with the same mycobacterial ssp. [69-80].

Transmission of mycobacteria via their gastrointestinal tract was confirmed by Actinobacteria detection in bats in China with $2.4 \%$ positivity in stomach samples and $15.7 \%$ positivity in intestinal samples [41]. Why are mycobacteria an important part of the microbiome in guano? Family Mycobacteriaceae belong to phylum Actinobacteria, which is widely spread in soil, surface water sediments, and water biofilms [36]. Members of 
genus Mycobacterium (esp. M. avium complex) are able to survive and propagate in such oligotrophic environments [81].

The clinical relevance with respect to classification into a risk group of biological agents for humans and animals was evaluated in identified species and ssp. according to the EC law (Directive 2000/54/EC and LPSN) [44,45]. The proportion of species and ssp. that belong to risk group 1 (environmental saprophytes) and risk group 2 (potentially pathogens) was almost equivalent (Table 6). No isolate belonged to risk group 3 (obligatory pathogens including $M$. tuberculosis, M. bovis, M. africanum, M. caprae, and other members of $M$. tuberculosis complex.) This favorable epidemiological finding could possibly be attributed to successful control programs against human and bovine tuberculosis in all studied countries [82].

The differences in the spectrum of mycobacteria detected in bat guano from the two different environments (caves and attics; Table 6) can be explained by a number of key biological and physical factors. Specifically, the physical conditions of the environment, the activities of the bats at the time which affects their commensal and other accompanying intestinal microflora such as winter hibernation vs. summer activities, and physiology of the detected mycobacterial sp. and ssp.

In particular, temperature and humidity are essential for the metabolic activity of mycobacteria. The air temperature in the caves of the Czech Republic fluctuated between 6.2-10.6 ${ }^{\circ} \mathrm{C}$. The temperature of the cave bedrock (underlying rocks and sediments) was slightly lower and ranged between $5.7-10.5^{\circ} \mathrm{C}$. Only in one cave (Zbrasov Aragonite Caves) did the temperature reach as high as $14.3^{\circ} \mathrm{C}$. [83]. Some mycobacteria (i.e., members of M. avium-intracellulare-scrofulaceum complex) can begin to grow at temperatures as low as $15.5^{\circ} \mathrm{C}$ [84]. At these low temperatures, mycobacteria may not grow but they can remain viable for a long time (months and even years) in living stage [36,85]. Environmental saprophytic mycobacteria can propagate when the air temperature rises above $18{ }^{\circ} \mathrm{C}$ [85].

Humidity in these caves in the Czech Republic ranged between 94.6-99.5\% [83]. In such high humid conditions, mycobacteria can sufficiently survive and multiply [36,85].

Conversely, the collection of attic-derived guano occurrs during summer, when the females Greater Mouse-eared Bats (Myotis myotis) give birth to young. At this time, temperatures in European attics can reach temperatures as high as $40{ }^{\circ} \mathrm{C}$ with relatively low humidity, typically between $25-60 \%$ [86]. These environmental conditions limit the metabolism and in some cases they can reduce the concentrations of living mycobacteria as well as degrade remnant mycobacterial DNA [36,85].

Another fundamental difference is the behaviour and activities of bats at the two types of locations. In our study, guano was collected from caves mainly during winter when bats were predominantly hibernating, whereas collection of guano from attics occurred during summer when the bats were fully active, including giving birth and taking care of young, resulting in a higher frequency of feeding and subsequent feces excretion. Furthermore, guano collected from summer colonies of the Greater Mouse-eared Bat (Myotis myotis) was subjected to more efficient decomposition compared to cave-derived guano. This was evident by statistically significantly higher values of conductivity and the presence of carbon in various forms (TC, TOC, TIC) in guano derived from attics compared to that from caves (Table 10 and Figure 4).

The degree of metabolism of active bats compared to those hibernating would affect the intestinal microflora, which accelerates the decomposition processes of the intestinal contents. Higher conductivity and the presence of a higher content of OC indicate the intense activity of microbes decomposing guano derived from the more active bats residing in attics. Other fast-growing intestinal microflora typically present include Clostridium sp., Bacillus sp., Proteus sp., Paenibacillus sp., Corynebacterium sp., and Flavobacterium sp. as well as other coliform Gram-negative rods that are able to degrade culture media in vitro in competition with mycobacteria [50].

In contrast, the cold environment of the caves results in suppression of the metabolic activity of the bat microflora; this was evident by a statistically significant lower EC, 
and lower concentration of TC and TOC, but a higher concentration of TIC (Table 10 and Figure 4). In the cold cave environment, guano remains intact for a long time [83] and consequently mycobacteria are likely able to remain viable within the guano for a substantial length of time (Tables 1 and 2). Under these conditions, significant active multiplication of mycobacteria would not be expected; in fact, it would be expected that long-term survival would have associated with a reduction in metabolism bordering on dormancy [36]. This assumption explains the higher uptake of mycobacterial DNA (Table 9 and Figure 3) and more frequent culture isolation of mycobacteria (Table 7). In contrast, guano derived from attics is subject to faster decomposition, which would result in viable mycobacterial cells being gradually outcompeted by fast growing bacteria and subsequently eliminated, as well as the rapid degradation of residual mycobacterial DNA (Tables 7 and 9 and Figure 3).

No differences were found between ORP and $\mathrm{pH}$ values between cave or attic-derived guano samples (Table 10 and Figure 4). This was probably due to the very similar molecular composition of the organic and inorganic components in both guano samples groups. These parameters may have a partial effect on the presence of living and/or unviable mycobacteria; to confirm this hypothesis, further investigation will be required not only in guano but also in fresh bat fecal samples. The ability of mycobacteria to tolerate variable $\mathrm{pH}$ is species specific [50]. However, the optimal $\mathrm{pH}$ range for most species is 5.4-7.4 [87].

With regard to the sp. and ssp. of mycobacteria isolated in this study, the $\mathrm{pH}$ values in both types of guano samples probably do not represent a limiting factor for their survival and possible multiplication (Table 6) [50]. ORP values in both types of guano indicated a slightly anoxic to oxidizing environment (Table 10 and Figure 4). These conditions are also unlikely to prevent the survival of mycobacteria. Again, further research is required to determine whether these physicochemical conditions effect the multiplication of other species of microorganisms that complicate culture detection of mycobacteria; frequent contamination of culture media during incubation complicates research in this field.

The specialization of various species of mycobacteria in dynamically changing environmental conditions has been demonstrated and is related to their genetic plasticity [88]. Some species of mycobacteria are able to respond more effectively to changes in the environment and adapt relatively quickly to new ecological conditions. Of the species of mycobacteria isolated in this study (Table 6), the most adaptable species is the potentially pathogenic M. avium ssp. hominissuis. This is a cosmopolitan ssp. that is able to colonize both various environmental niches and humans $[36,85,89,90]$.

Environmentally saprophytic mycobacterial species detected in guano from both sources were $M$ terrae and $M$. arupense (belonging to $M$. terrae complex), and $M$. fortuitum (Table 6). These mycobacterial species were apparently able to withstand competition with other microorganisms and, at a certain stage of guano decomposition, to temporarily predominate and/or coexist with the rest of the microflora. Generally, mycobacteria are slow growing, which is attributed to the construction of a complex cell wall and inefficient metabolism [36,85], however, it is thought they play an important role as "pioneers" in the settlement of new substrates, making unhospitable conditions more amenable for growth of other bacterial species; the cave environment is such an environment, with its extremely low levels of organic matter [83].

The amount of mycobacteria captured and their species spectrum in guano may not be final. Due to the physiological properties of mycobacteria (their slow metabolism and long generation time), the processing of highly microbially loaded samples is very difficult. The differences in the detection of mycobacteria by the methods we use are obvious and statistically substantiated (Table 2). Microscopic examination has variable but in many cases low sensitivity [91].

In addition to mycobacterial cells, a number of $\mathrm{G}+$ microbial flora and artifacts are present in environmental matrices, which can also be stained red after using the ZN method and can complicate the objective evaluation of the presence of mycobacteria; so-called false microscopic positivity. The qPCR method used has acceptable specificity and higher 
sensitivity [50]. However, as with microscopic examination, it is not possible to assess the viability of captured mycobacteria using the standard qPCR method. Dead mycobacterial cells or only residues of their genetic material may be present in the samples. Of course, the specificity of DNA capture in the performed method is not absolute. Non-specific sections of genetic material that are not of mycobacterial origin may be detected in the samples; so-called false qPCR negativity [92].

The culture test should have the highest sensitivity and specificity and clearly detect viable mycobacterial cells. Nevertheless, the reliability of cultivation can be limited. The sample processing process itself may affect the viability of the mycobacteria present. The aim is to achieve the lowest level of culture contamination and acceptable capture yield of the target micro-organism (mycobacteria). It can be accepted that some species of mycobacteria can be eliminated for cultivation by processing the matrix itself [93]. Further development of sufficiently sensitive and specific detection methods is therefore highly desirable.

In terms of competing with other bacteria, mycobacteria are less able to actively colonize guano and other matrices due to the physiological properties described above. However, as some oligotrophic microorganisms, they are more resistant and persistent in these unfavorable conditions of karst caves [36,85]. Some positive culture-determined proven (viable) species of mycobacteria were isolated exclusively from guano collected from caves (Table 6). They are likely to be transported by bats that are infected from their food sources. Their ability to survive long term in adverse conditions (low temperature, small amounts of organic material, etc.) as well as their ability to remain dormant over a long period of time in this environment has allowed them to become important representatives of the microflora within both the natural environments as well as the digestive system of bats.

\section{Conclusions}

Nontuberculous mycobacteria (NTM) were found in both attics and caves, but the number of mycobacteria in guano from the caves was more than double that from the attic. Among the isolates, no mycobacterial species belonging to the third risk group (obligatory pathogens including $M$. tuberculosis complex members) were found, $22.5 \%$ of isolates belonged to risk group 1 (environmental saprophytes) and 53.9\% isolates belonged to risk group 2 (potential pathogens). NTM were isolated from guano samples collected from caves in all eight European countries (Bulgaria, Czech Republic, France, Hungary, Italy, Romania, Slovakia, and Slovenia. The correlation of detection of mycobacteria between Ziehl-Neelsen (ZN) microscopy and culture examination and qPCR was strong. Detection of mycobacteria by $\mathrm{ZN}$ microscopy examination in guano collected from caves (58.6\%) was more than double that detected in guano collected from attics and roof structures $(21.0 \% ; p<0.01)$. When comparing bat guano collected from the two different sources, statistically highly significant differences $(p<0.01$; Mann-Whitney test) were observed for the following parameters: electrical conductivity, total carbon, and total organic and total inorganic carbon. In contrast, no statistically significant difference $(p>0.05$; Mann-Whitney test) was found when comparing the $\mathrm{pH}$ and oxidation-reduction potential parameters.

Author Contributions: Methodology: I.P., V.U., H.M., M.G., B.R., J.Z. and K.Z.; investigation: I.P., V.U., H.M., O.K., V.K. and P.K.; resources: J.Z., K.Z., V.K. and P.K.; data curation: H.M., M.G., B.R., V.B. and R.T.W.; writing—original draft preparation: I.P.; writing—review and editing: V.U., H.M., M.G., O.K., V.B. and R.T.W.; visualization: O.K. and V.B.; supervision: I.P. and J.Z. All authors have read and agreed to the published version of the manuscript.

Funding: This research was financially supported by the Czech Science Foundation No. 21-12719S.

Institutional Review Board Statement: Not applicable.

Informed Consent Statement: Not applicable. 
Data Availability Statement: Availability of data and materials correspondence and requests for mycobacterial isolates be addressed to the corresponding author.

Acknowledgments: We would like to acknowledge the following chiropterologists and speleologists for the collection of guano samples (in alphabetical order): Andreas M., Benda P., Berkova H., Buric Z., Franek B., Hanzal V., Hetesi J., Horacek D., Kovarik M., Lesinsky G., Lo Papa G., Musil F., Portes M., Reiter A., Svacina T., and Safar J., speleologists: Stefka L., Svozil J., Tuma A., and Vattano M., and co-workers for technical assistance: Bartos M., Caha J., Hubelova D., Kaucka P., Kantorova H., Kracalikova A., Kudelka J., Somerlikova K., and Vlkova M.

Conflicts of Interest: The author declares no conflict of interest.

\section{References}

1. Calisher, C.H.; Childs, J.E.; Field, H.E.; Holmes, K.V.; Schountz, T. Bats: Important reservoir hosts of emerging viruses. Clin. Microbiol. Rev. 2006, 19, 531-545. [CrossRef] [PubMed]

2. Muhldorfer, K. Bats and bacterial pathogens: A review. Zoonoses Public Health 2013, 60, 93-103. [CrossRef]

3. Yon, L.; Duff, J.P.; Agren, E.O.; Erdelyi, K.; Ferroglio, E.; Godfroid, J.; Hars, J.; Hestvik, G.; Horton, D.; Kuiken, T.; et al. Recent changes in infectious diseases in European wildlife. J. Wildl. Dis. 2019, 55, 3-43. [CrossRef] [PubMed]

4. Fagre, A.C.; Kading, R.C. Can bats serve as reservoirs for arboviruses? Viruses 2019, 11, 215. [CrossRef]

5. Letko, M.; Seifert, S.N.; Olival, K.J.; Plowright, R.K.; Munster, V.J. Bat-borne virus diversity, spillover and emergence. Nat. Rev. Microbiol. 2020, 18, 461-471. [CrossRef]

6. Llanos-Soto, S.; Gonzalez-Acuna, D. Knowledge about bacterial and viral pathogens present in wild mammals in Chile: A systematic review. Rev. Chil. Infectol. 2019, 36, 195-218. [CrossRef]

7. Shipley, R.; Wright, E.; Selden, D.; Wu, G.; Aegerter, J.; Fooks, A.R.; Banyard, A.C. Bats and viruses: Emergence of novel Lyssaviruses and association of bats with viral zoonoses in the EU. Trop. Med. Infect. Dis. 2019, 4, 31. [CrossRef] [PubMed]

8. Di Salvo, A.F.; Ajello, L.; Palmer, J.W.; Winkler, W.G. Isolation of Histoplasma capsulatum from Arizona bats. Am. J. Epidemiol. 1969, 89, 606-614. [CrossRef]

9. De Perio, M.A.; Benedict, K.; Williams, S.L.; Niemeier-Walsh, C.; Green, B.J.; Coffey, C.; Di Giuseppe, M.; Toda, M.; Park, J.H.; Bailey, R.L.; et al. Occupational histoplasmosis: Epidemiology and prevention measures. J. Fungi 2021, 7, 510. [CrossRef]

10. McClean, M.C.W.; Bhattacharyya, T.; Mertens, P.; Murphy, N.; Gilleman, Q.; Gustin, Y.; Zeippen, N.; Xavier, S.C.C.; Jansen, A.M.; Miles, M.A. A lineage-specific rapid diagnostic test (Chagas Sero K-SeT) identifies Brazilian Trypanosoma cruzi II/V/VI reservoir hosts among diverse mammalian orders. PLOS ONE 2020, 15, e0227828. [CrossRef]

11. Mulec, J.; Dietersdorfer, E.; Ustunturk-Onan, M.; Walochnik, J. Acanthamoeba and other free-living amoebae in bat guano, an extreme habitat. Parasitol. Res. 2016, 115, 1375-1383. [CrossRef]

12. Asante, J.; Noreddin, A.; El Zowalaty, M.E. Systematic review of important bacterial zoonoses in Africa in the last decade in light of the 'One Health' Concept. Pathogens 2019, 8, 50. [CrossRef] [PubMed]

13. Afonso, E.; Goydadin, A.C. Molecular detection of Anaplasma phagocytophilum DNA in the lesser horseshoe bat (Rhinolophus hipposideros) guano. Epidemiol. Infect. 2018, 146, 1253-1258. [CrossRef]

14. Kosoy, M.; Bai, Y.; Lynch, T.; Kuzmin, I.V.; Niezgoda, M.; Franka, R.; Agwanda, B.; Breiman, R.F.; Rupprecht, C.E. Bartonella spp. in bats, Kenya. Emerg. Infect. Dis. 2010, 16, 1875-1881. [CrossRef] [PubMed]

15. Lei, B.R.; Olival, K.J. Contrasting patterns in mammal-bacteria coevolution: Bartonella and Leptospira in bats and rodents. PLoS Negl. Trop. Dis. 2014, 8, e2738. [CrossRef]

16. Veikkolainen, V.; Vesterinen, E.J.; Lilley, T.M.; Pulliainen, A.T. Bats as reservoir hosts of human bacterial pathogen, Bartonella mayotimonensis. Emerg. Infect. Dis. 2014, 20, 960-967. [CrossRef]

17. Corduneanu, A.; Sándor, A.D.; Ionica, A.M.; Hornok, S.; Leitner, N.; Bago, Z.; Stefke, K.; Fuehrer, H.P.; Mihalca, A.D. Bartonella DNA in heart tissues of bats in central and eastern Europe and a review of phylogenetic relations of bat-associated bartonellae. Parasit. Vectors 2018, 11, 489. [CrossRef]

18. Szubert-Kruszynska, A.; Stanczak, J.; Cieniuch, S.; Podsiadły, E.; Postawa, T.; Michalik, J. Bartonella and Rickettsia infections in haematophagous Spinturnix myoti mites (Acari: Mesostigmata) and their bat host, Myotis myotis (Yangochiroptera: Vespertilionidae), from Poland. Microb. Ecol. 2019, 77, 759-768. [CrossRef]

19. Ferreira, M.S.; Guterres, A.; Rozental, T.; Novaes, R.L.M.; Vilar, E.M.; Oliveira, R.C.; Fernandes, J.; Forneas, D.; Junior, A.A.; Brandão, M.L.; et al. Coxiella and Bartonella spp. in bats (Chiroptera) captured in the Brazilian Atlantic Forest biome. BMC Vet. Res. 2018, 14, 279. [CrossRef]

20. Nowakiewicz, A.; Zieba, P.; Gnat, S.; Osinska, M.; Lagowski, D.; Kosior-Korzecka, U.; Puzio, I.; Krol, J. Analysis of the occurrence and molecular characteristics of drug-resistant strains of Enterococcus faecalis isolated from the gastrointestinal tract of insectivorous bat species in Poland: A possible essential impact on the spread of drug resistance? Environ. Pollut. 2021, 269, 116099. [CrossRef] [PubMed]

21. Seidlova, V.; Nemcova, M.; Pikula, J.; Bartonicka, T.; Ghazaryan, A.; Heger, T.; Kokurewicz, T.; Orlov, O.L.; Patra, S.; Piacek, V.; et al. Urinary shedding of leptospires in Palearctic bats. Transbound Emerg. Dis. 2021. online ahead of print. [CrossRef] [PubMed] 
22. Volokhov, D.V.; Becker, D.J.; Bergner, L.M.; Camus, M.S.; Orton, R.J.; Chizhikov, V.E.; Altizer, S.M.; Streicker, D.G. Novel hemotropic mycoplasmas are widespread and genetically diverse in vampire bats. Epidemiol. Infect. 2017, 145, 3154-3167. [CrossRef] [PubMed]

23. Millan, J.; Cevidanes, A.; Sacristan, I.; Alvarado-Rybak, M.; Sepulveda, G.; Ramos-Mella, C.A.; Lison, F. Detection and characterization of hemotropic mycoplasmas in bats in Chile. J. Wildl. Dis. 2019, 55, 977-981. [CrossRef] [PubMed]

24. Blehert, D.S.; Maluping, R.P.; Green, D.E.; Berlowski-Zier, B.M.; Ballmann, A.E.; Langenberg, J.A. Acute pasteurellosis in wild big brown bats (Eptesicus fuscus). J. Wildl. Dis. 2014, 50, 136-139. [CrossRef] [PubMed]

25. Vandzurova, A.; Backor, P.; Javorsky, P.; Pristas, P. Staphylococcus nepalensis in the guano of bats (Mammalia). Vet. Microbiol. 2013, 164, 116-121. [CrossRef] [PubMed]

26. De Leon, M.P.; Park, A.Y.; Montecillo, A.D.; Siringan, M.A.T.; Rosana, A.R.R.; Kim, S.G. Near-complete genome sequences of Streptomyces sp. Strains AC1-42T and AC1-42W, isolated from bat guano from Cabalyorisa Cave, Mabini, Pangasinan, Philippines. Microbiol. Resour. Announc. 2018, 7, e00904-18. [CrossRef]

27. Gerbacova, K.; Malinicova, L.; Kiskova, J.; Maslisova, V.; Uhrin, M.; Pristas, P. The faecal microbiome of building-dwelling insectivorous bats (Myotis myotis and Rhinolophus hipposideros) also contains antibiotic-resistant bacterial representatives. Curr. Microbiol. 2020, 77, 2333-2344. [CrossRef] [PubMed]

28. Pavlik, I.; Falkinham, J. The occurrence of pathogenic and potentially pathogenic mycobacteria in animals and the role of the environment in the spread of infection. Chapter 6. In The Ecology of Mycobacteria: Impact on Animal's and Human's Health, 1st ed.; Kazda, J., Pavlik, I., Falkinham, J., Hruska, K., Eds.; Springer: Dordrecht, The Netherlands; Berlin/Heidelberg, Germany; London, UK; New York, NY, USA, 2009; pp. 199-281.

29. Scott, H. Report on the deaths occurring in the society's gardens during the year 1925. Proc. Zool. Soc. Lond. 1926, 96, 231-244. [CrossRef]

30. Griffith, A. Tuberculosis in captive wild animals. J. Hyg. 1928, 29, 198-218. [CrossRef]

31. Hamerton, A. Report on the deaths occurring in the Society's Gardens during the year 1930. Proc. Zool. Soc. Lond. 1931, 101, 527-555. [CrossRef]

32. Runyon, E.H. Pathogenic mycobacteria. Adv. Tuberc. Res. 1965, 21, 235-287.

33. Clark, H.F.; Shepard, C.C. Effect of environmental temperatures on infection with Mycobacterium marinum (balnei) of mice and a number of poikilothermic species. J. Bacteriol. 1963, 86, 1057-1069. [CrossRef] [PubMed]

34. Church, J.C.; Griffin, E.R. Mycobacterium buruli lesions in the fruit bat web. J. Pathol. Bacteriol. 1968, 96, 508-512. [CrossRef] [PubMed]

35. Buckle, G. Notes on Mycobacterium ulcerans. ANZ J. Surg. 1972, 41, 320-323. [CrossRef]

36. Pavlik, I.; Falkinham, J.; Kazda, J. Environments providing favourable conditions for the multiplication and transmission of mycobacteria. Chapter 5. In The Ecology of Mycobacteria: Impact on Animal's and Human's Health, 1st ed.; Kazda, J., Pavlik, I., Falkinham, J., Hruska, K., Eds.; Springer: Dordrecht, The Netherlands; Berlin/Heidelberg, Germany; London, UK; New York, NY, USA, 2009; pp. 89-197.

37. De Mandal, S.; Panda, A.K.; Lalnunmawii, E.; Bisht, S.S.; Kumar, N.S. Illumina-based analysis of bacterial community in Khuangcherapuk cave of Mizoram, Northeast India. Genom. Data 2015, 5, 13-14. [CrossRef] [PubMed]

38. Banskar, S.; Bhute, S.S.; Suryavanshi, M.V.; Punekar, S.; Shouche, Y.S. Microbiome analysis reveals the abundance of bacterial pathogens in Rousettus leschenaultii guano. Sci. Rep. 2016, 6, 36948. [CrossRef]

39. De Mandal, S.; Zothansanga; Panda, A.K.; Bisht, S.S.; Senthil Kumar, N. First report of bacterial community from a bat guano using Illumina next-generation sequencing. Genom. Data 2015, 4, 99-101. [CrossRef]

40. De Leon, M.P.; Montecillo, A.D.; Pinili, D.S.; Siringan, M.A.T.; Park, D.S. Bacterial diversity of bat guano from Cabalyorisa Cave, Mabini, Pangasinan, Philippines: A first report on the metagenome of Philippine bat guano. PLoS ONE 2018, 13, e0200095. [CrossRef]

41. Yuan, Z.; Yu, Y.; Wang, Y.; Bu, Y.; Niu, H. Microbial diversity in the gastrointestinal tract of a bat, Hypsugo alaschanicus. Pak. J. Zool. 2019, 51, 1807-1813. [CrossRef]

42. Selvin, J.; Lanong, S.; Syiem, D.; De Mandal, S.; Kayang, H.; Kumar, N.S.; Kiran, G.S. Culture-dependent and metagenomic analysis of lesser horseshoe bats' gut microbiome revealing unique bacterial diversity and signatures of potential human pathogens. Microb. Pathog. 2019, 137, 103675. [CrossRef]

43. Modra, H.; Bartos, M.; Hribova, P.; Ulmann, V.; Hubelova, D.; Konecny, O.; Gersl, M.; Kudelka, J.; Voros, D.; Pavlik, I. Detection of mycobacteria in the environment of the Moravian Karst (Bull Rock Cave and the relevant water catchment area): The impact of water sediment, earthworm castings and bat guano. Vet. Med.-Czech. 2017, 62, 153-168. [CrossRef]

44. LPSN: List of Prokaryotic Names with Standing in Nomenclature. Available online: https://lpsn.dsmz.de/ (accessed on 25 October 2021).

45. European Union. Directive 2000/54/EC of the European Parliament and of the Council of 18 September 2000 on the protection of workers from risks related to exposure to biological agents at work. Off. J. Eur. Communities 2000, L262, 21-45.

46. Chronakova, A.; Horak, A.; Elhottova, D.; Kristufek, V. Diverse archaeal community of a bat guano pile in Domica Cave (Slovak Karst, Slovakia). Folia Microbiol. 2009, 54, 436-446. [CrossRef]

47. D'Angeli, I.M.; Serrazanetti, D.I.; Montanari, C.; Vannini, L.; Gardini, F.; De Waele, J. Geochemistry and microbial diversity of cave waters in the gypsum karst aquifers of Emilia Romagna region, Italy. Sci. Total Environ. 2017, 598, 538-552. [CrossRef] 
48. Zukal, J.; Berkova, H.; Rehak, Z. Activity and shelter selection by Myotis myotis and Rhinolophus hipposideros hibernating in the Katerinska Cave (Czech Republic). Mammal. Biol. 2005, 70, 271-281. [CrossRef]

49. Ulmann, V.; Kracalikova, A.; Dziedzinska, R. Mycobacteria in water used for personal hygiene in heavy industry and collieries: A potential risk for employees. Int. J. Environ. Res. Public Health 2015, 12, 2870-2877. [CrossRef] [PubMed]

50. Ulmann, V.; Modra, H.; Babak, V.; Weston, R.T.; Pavlik, I. Recovery of mycobacteria from heavily contaminated environmental matrices. Microorganism 2021, 9, 2178. [CrossRef]

51. Slana, I.; Kaevska, M.; Kralik, P.; Horvathova, A.; Pavlik, I. Distribution of Mycobacterium avium subsp. avium and M. a. hominissuis in artificially infected pigs studied by culture and IS901 and IS1245 quantitative real time PCR. Vet. Microbiol. 2010, 26, 437-443. [CrossRef] [PubMed]

52. De Vaus, D. Survey in Social Research, 5th ed.; Rutledge: London, UK, 2002; 422p.

53. Shannon, C.E.; Wiener, W. The Mathematical Theory of Communication; University of Illinois Press: Urbana, IL, USA, 1949; 177p.

54. Davis, J.J.; Gulson, B.L. Ceiling (attic) dust: A “museum" of contamination and potential hazard. Environ. Res. 2005, 99, 177-194. [CrossRef] [PubMed]

55. Wheeler, A.J.; Jones, P.J.; Reisen, F.; Melody, S.M.; Williamson, G.; Strandberg, B.; Hinwood, A.; Almerud, P.; Blizzard, L.; Chappell, K.; et al. Roof cavity dust as an exposure proxy for extreme air pollution events. Chemosphere 2020, 244, 125537. [CrossRef]

56. Varghese, B.; Al-Hajoj, S. A global update on rare non-tuberculous mycobacteria in humans: Epidemiology and emergence. Int. J. Tuberc. Lung. Dis. 2020, 24, 214-223. [CrossRef] [PubMed]

57. McAney, C.M.; Fairley, J.S. Analysis of the diet of the lesser horseshoe bat Rhinolophus hipposideros in the West of Ireland. J. Zool. 1989, 217, 491-498. [CrossRef]

58. Bono, S.; Toffoli, R. Diet of Rhinolophus hipposideros during breeding season in the south-western Italian Alps. Vespertilio 2016, 18, 29-39.

59. Aldasoro, M.; Garin, I.; Vallejo, N.; Baroja, U.; Arrizabalaga-Escudero, A.; Goiti, U.; Aihartza, J. Gaining ecological insight on dietary allocation among horseshoe bats through molecular primer combination. PLoS ONE 2019, 14, e022008. [CrossRef]

60. Siemers, B.M.; Guttinger, R. Prey conspicuousness can explain apparent prey selectivity. Curr. Biol. 2006, 16, R157-R159. [CrossRef]

61. Arlettaz, R.; Perrin, N.; Hausser, J. Trophic resource partitioning and competition between the two sibling bat species Myotis myotis and Myotis blythii. J. Anim. Ecol. 1997, 66, 897-911. [CrossRef]

62. Pereira, M.J.R.; Rebelo, H.; Rainho, A.; Palmeirim, J.M. Prey selection by Myotis myotis (Vespertilionidae) in a Mediterranean Region. Acta Chiropterol. 2002, 4, 183-193. [CrossRef]

63. Strobel, S.; Roswag, A.; Becker, N.I.; Trenczek, T.E.; Encarnacao, J.A. Insectivorous bats digest chitin in the stomach using acidic mammalian chitinase. PLoS ONE 2013, 8, e72770. [CrossRef]

64. Kaya, M.; Seyyar, O.; Baran, T.; Turkes, T. Bat guano as new and attractive chitin and chitosan source. Front. Zool. 2014, 11, 59. [CrossRef]

65. Zingue, D.; Bouam, A.; Tian, R.B.D.; Drancourt, M. Buruli ulcer, a prototype for ecosystem-related infection, caused by Mycobacterium ulcerans. Clin. Microbiol. Rev. 2017, 31, e00045-17.

66. Sanhueza, D.; Chevillon, C.; Colwell, R.; Babonneau, J.; Marion, E.; Marsollier, L.; Guegan, J.F. Chitin promotes Mycobacterium ulcerans growth. FEMS Microbiol. Ecol. 2016, 92, fiw067. [CrossRef]

67. Sanhueza, D.; Chevillon, C.; Bouzinbi, N.; Godreuil, S.; Guegan, J.F. Chitin increases Mycobacterium ulcerans growth in acidic environments. Microbes Environ. 2018, 33, 234-237. [CrossRef]

68. Talamantes, D.; Biabini, N.; Dang, H.; Abdoun, K.; Berlemont, R. Natural diversity of cellulases, xylanases, and chitinases in bacteria. Biotechnol. Biofuels 2016, 9, 133. [CrossRef] [PubMed]

69. Fischer, O.; Matlova, L.; Dvorska, L.; Svastova, P.; Bartl, J.; Melicharek, I.; Weston, R.T.; Pavlik, I. Diptera as vectors of mycobacterial infections in cattle and pigs. Med. Vet. Entomol. 2001, 15, 208-211. [CrossRef] [PubMed]

70. Fischer, O.A.; Matlova, L.; Bartl, J.; Dvorska, L.; Svastova, P.; du Maine, R.; Melicharek, I.; Bartos, M.; Pavlik, I. Earthworms (Oligochaeta, Lumbricidae) and mycobacteria. Vet. Microbiol. 2003, 91, 325-338. [CrossRef]

71. Fischer, O.A.; Matlova, L.; Dvorska, L.; Svastova, P.; Pavlik, I. Nymphs of the Oriental cockroach (Blatta orientalis) as passive vectors of causal agents of avian tuberculosis and paratuberculosis. Med. Vet. Entomol. 2003, 17, 145-150. [CrossRef] [PubMed]

72. Fischer, O.A.; Matlova, L.; Dvorska, L.; Svastova, P.; Bartl, J.; Weston, R.T.; Pavlik, I. Blowflies Calliphora vicina and Lucilia sericata as passive vectors of Mycobacterium avium subsp. avium, M. a. paratuberculosis and M. a. hominissuis. Med. Vet. Entomol. 2004, 18, 116-122. [CrossRef]

73. Fischer, O.A.; Matlova, L.; Dvorska, L.; Svastova, P.; Peral, D.L.; Weston, R.T.; Bartos, M.; Pavlik, I. Beetles as possible vectors of infections caused by Mycobacterium avium species. Vet. Microbiol. 2004, 102, 247-255. [CrossRef]

74. Fischer, O.A.; Matlova, L.; Dvorska, L.; Svastova, P.; Bartos, M.; Weston, R.T.; Kopecna, M.; Trcka, I.; Pavlik, I. Potential risk of Mycobacterium avium subspecies paratuberculosis spread by syrphid flies in infected cattle farms. Med. Vet. Entomol. 2005, 19, 360-366. [CrossRef]

75. Fischer, O.A.; Matlova, L.; Dvorska, L.; Svastova, P.; Bartos, M.; Weston, R.T.; Pavlik, I. Various stages in the life cycle of syrphid flies (Eristalis tenax; Diptera: Syrphidae) as potential mechanical vectors of pathogens causing mycobacterial infections in pig herds. Folia Microbiol. 2006, 51, 147-153. [CrossRef] 
76. Dvorska, L.; Matlova, L.; Ayele, W.Y.; Fischer, O.A.; Amemori, T.; Weston, R.T.; Alvarez, J.; Beran, V.; Moravkova, M.; Pavlik, I. Avian tuberculosis in naturally infected captive water birds of the Ardeidae and Threskiornithidae families studied by serotyping, IS901 RFLP typing and virulence for poultry. Vet. Microbiol. 2007, 119, 366-374. [CrossRef] [PubMed]

77. Kaevska, M.; Slana, I.; Kralik, P.; Reischl, U.; Orosova, J.; Holcikova, A.; Pavlik, I. "Mycobacterium avium subsp. hominissuis" in neck lymph nodes of children and their environment examined by culture and triplex quantitative real time PCR. J. Clin. Microbiol. 2011, 49, 167-172. [CrossRef] [PubMed]

78. Krizova, K.; Matlova, L.; Horvathova, A.; Moravkova, M.; Beran, V.; Boisselet, T.; Babak, V.; Slana, I.; Pavlik, I. Mycobacteria in the environment of pig farms in the Czech Republic between 2003 and 2007. Vet. Med.-Czech. 2010, 55, 55-69. [CrossRef]

79. Matlova, L.; Dvorska, L.; Bartl, J.; Bartos, M.; Ayele, W.Y.; Alexa, M.; Pavlik, I. Mycobacteria isolated from the environment of pig farms in the Czech Republic during the years 1996 to 2002. Vet. Med.-Czech. 2003, 48, 343-357. [CrossRef]

80. Moravkova, M.; Lamka, J.; Kriz, P.; Pavlik, I. The presence of Mycobacterium avium subsp. avium in common pheasants (Phasianus colchicus) living in captivity and in other birds, vertebrates, non-vertebrates and the environment. Vet. Med.-Czech. 2011, 56, 333-343. [CrossRef]

81. Zhu, J.; Liu, R.; Cao, N.; Yu, J.; Liu, X.; Yu, Z. Mycobacterial metabolic characteristics in a water meter biofilm revealed by metagenomics and metatranscriptomics. Water Res. 2019, 153, 315-323. [CrossRef]

82. Pavlik, I. Status of bovine tuberculosis control in countries of Central Europe and countries of the former Soviet Union. Chapter 32. In Zoonotic Tuberculosis: Mycobacterium Bovis and Other Pathogenic Mycobacteria, 3rd ed.; Thoen, C.O., Steele, J.H., Kaneene, J.B., Eds.; Wiley-Blackwell: Chichester, UK, 2014; pp. 369-382.

83. Hromas, J. Caves. In Protected Areas in the Czech Republic, 1st ed.; Mackovcin, P., Sedlacek, M., Eds.; Agentura Ochrany Prirody a Krajiny CR a EkoCentrum Brno: Praha, Czech Republic, 2009; Volume XIV, 608p. (In Czech)

84. George, K.L.; Parker, B.C.; Gruft, H.; Falkinham, J.O., 3rd. Epidemiology of infection by nontuberculous mycobacteria. II. Growth and survival in natural waters. Am. Rev. Respir. Dis. 1980, 122, 89-94.

85. Kazda, J. The Ecology of Mycobacteria; Kluwer Academic Publishers: Dordrecht, Germany; Boston, MA, USA; London, UK, 2000; $72 \mathrm{p}$.

86. Bartonicka, T.; Ruzickova, L. Bat bugs (Cimex pipistrelli) and their impact on non-dwelling bats. Parasitol. Res. 2012, 111, 1233-1238. [CrossRef] [PubMed]

87. Portaels, F.; Pattyn, S.R. Growth of mycobacteria in relation to the pH of the medium. Ann. Microbiol. 1982, 133, $213-221$.

88. Cox, R.A.; Garcia, M.J. Adaptation of mycobacteria to growth conditions: A theoretical analysis of changes in gene expression revealed by microarrays. PLoS ONE 2013, 8, e59883. [CrossRef]

89. Kannan, N.; Lai, Y.P.; Haug, M.; Lilleness, M.K.; Bakke, S.S.; Marstad, A.; Hov, H.; Naustdal, T.; Afset, J.E.; Ioerger, T.R.; et al. Genetic variation/evolution and differential host responses resulting from in-patient adaptation of Mycobacterium avium. Infect. Immun. 2019, 87, e00323-18. [CrossRef] [PubMed]

90. Yano, H.; Iwamoto, T.; Nishiuchi, Y.; Nakajima, C.; Starkova, D.A.; Mokrousov, I.; Narvskaya, O.; Yoshida, S.; Arikawa, K.; Nakanishi, N.; et al. Population structure and local adaptation of MAC lung disease agent Mycobacterium avium subsp. hominissuis. Genome. Biol. Evol. 2017, 9, 2403-2417. [CrossRef]

91. Lipsky, B.A.; Gates, J.; Tenover, F.C.; Plorde, J.J. Factors affecting the clinical value of microscopy for acid-fast bacilli. Rev. Infect. Dis. 1984, 6, 214-622. [CrossRef] [PubMed]

92. Radomski, N.; Lucas, F.S.; Moilleron, R.; Cambau, E.; Haenn, S.; Moulin, L. Development of a real-time qPCR method for detection and enumeration of Mycobacterium spp. in surface water. Appl. Environ. Microbiol. 2010, 76, 7348-7351. [CrossRef]

93. Stephenson, D.; Perry, A.; Nelson, A.; Robb, A.E.; Thomas, M.F.; Bourke, S.J.; Perry, J.D.; Jones, A.L. Decontamination strategies used for AFB culture significantly reduce the viability of Mycobacterium abscessus complex in sputum samples from patients with cystic fibrosis. Microorganisms 2021, 9, 1597. [CrossRef] [PubMed] 